\title{
Sensitivity analysis of a simplified precipitation-runoff model to estimate water availability in Southern Portuguese watersheds
}

\section{Analisi di sensitività di un modello semplificato di precipitazione-deflusso per stimare la disponibilità di acqua nei bacini idrici del Portogallo meridionale}

\author{
Tiago N. Martins ${ }^{\mathrm{a}} \stackrel{\text { 军, Manuel M. Oliveira }}{\mathrm{a}}$, Maria M. Portela $^{\mathrm{b}}$, Teresa E. Leitão $^{\mathrm{a}}$ \\ aHydraulics and Environment Department, National Laboratory for Civil Engineering, Lisbon, Portugal - email: tmartins@lnec.pt; \\ moliveira@lnec.pt; tleitao@lnec.pt \\ ${ }^{\mathrm{b}}$ Technical University of Lisbon | UTL · Department of Civil Engineering and Architecture (DECivil) email: maria.manuela.portela@tecnico.ulisboa.pt
}

\section{ARTICLE INFO \\ Ricevuto/Received: 03 May 2021 Accettato/Accepted: 25 June 2021 Pubblicato online/Published online: 30 June 2021 \\ Editor: Matteo Cultrera}

\section{Citation:}

Tiago N. Martins, Manuel M. Oliveira, Maria M. Portela , Teresa E. Leitão (2021) Sensitivity analysis of a simplified precipitation-runoff model to estimate water availability in Southern Portuguese watersheds. Acque Sotterranee - Italian Journal of Groundwater, 10(2), 33 - 47 https://doi.org/10.7343/as-2021-514

Correspondence to:

Tiago N. Martins : tmartins@lnec.pt
Keywords: surface runoff, aquifer recharge, bydrological modelling, daily sequential soil-water budget, BALSEQ.

Parole chiave: ruscellamento superficiale, ricarica della falda, modellazione idrologica, bilancio sequenziale giornaliero suolo-acqua, BALSEQ

Copyright: (C) 2021 by the authors Licensee Associazione Acque Sotterranee This is an open access article under the CC BY-NC-ND license: http://creativecommons.org/licenses/bync-nd/4.0/

\section{Riassunto}

La stima della disponibilità idrica nelle grandi regioni è una procedura importante nella definizione di una politica di gestione delle risorse idriche ad ampio spettro, ma può rivelarsi difficile a causa della mancanza di dati e dell'incertezza sulla relativa caratterizzazione idrologica ed idrogeologica regionale. BALSEQ, un modello di bilancio idrico sequenziale giornaliero, è stato implementato in una serie di ventidue bacini idrografici nel sud del Portogallo, con l'obiettivo di comprendere le possibili relazioni tra i parametri del modello e le caratteristiche dei bacini idrografici che possono consentire l'assemblaggio di funzioni di calibrazione per quei bacini idrografici che non sono monitorati. È stata condotta un'analisi di sensitività confrontando i risultati di BALSEQ con il deflusso superficiale misurato, concentrandosi in particolare sulla frazione della potenziale ritenzione massima $(\varphi)$ e la quantità massima di acqua disponibile nel suolo per i parametri di evapotraspirazione (AGUT) e il modello concettuale idrogeologico sottostante che controlla infine le interazioni tra superficie e falda.

I risultati complessivi non hanno permesso di identificare relazioni chiare che consentano l'estrapolazione ad altre regioni prive di dati, in quanto le procedure di analisi di sensitività hanno restituito risultati simili per ampi intervalli di parametri per la maggior parte dei bacini idrografici. I risultati hanno confermato che il contributo delle acque sotterranee è una componente importante per il deflusso superficiale complessivo misurato e che il parametro $\varphi$ non deve essere trascurato nel calcolo del ruscellamento superficiale. Sono stati osservati scarsi aggiustamenti complessivi tra i risultati del modello e il flusso misurato in bacini idrografici con un basso rapporto flusso superficiale - precipitazioni.

\footnotetext{
Abstract

The water availability estimation in large regions is a relevant procedure to define broad water resources management policies but may prove difficult due to the lack of data and uncertainty to related regional bydrological and bydrogeological characterization. BALSEQ, a daily sequential water budget model, was applied in a set of twenty-two watersheds in southern Portugal, aiming to understand the possible relations between the model parameters and watershed characteristics that may allow assembling calibration functions for non-monitored watersheds. A sensitivity analysis was conducted by comparing BALSEQ results with measured surface flow, focusing specifically on the fraction of the potential maximum retention $(\varphi)$ and the maximum amount of water available in the soil for evapotranspiration (AGUT) parameters and the underlying hydrogeological conceptual model that ultimately controls the surface-groundwater interactions. The overall results did not allow to identify clear relations that permit extrapolation to other regions without data as the sensitivity analysis procedures returned similar results for wide intervals of parameters for the majority of watersheds. The results confirmed that the groundwater discharge is an important component for the total measured surface flow and that the $\varphi$ parameter should not be overlooked when calculating direct runoff. Poor adjustments between the model results and measured flow were observed in watersheds with a low Surface flow - Rainfall ratio.
} 


\section{Inroduction}

The characterisation of surface runoff and aquifer recharge is a fundamental procedure in water resources and watershed management (Sophocleous 2002). Being surface water availability one of the main factors for the successful implementation of alternative water management techniques such as managed aquifer recharge (MAR) (Dillon et al. 2009; Maliva 2014; Page et al. 2018; Alam et al. 2021), daily characterization of the behaviour of different hydrological components may be of relevance for watershed management, including the definition of solutions to mitigate the effects of extreme events, such as floods, while increasing groundwater storage. The precise recharge calculation is also an essential process to characterize and manage the exploitable volume of groundwater (Oliveira, 2006).

For this kind of characterization in large regions, where lack of data is common, the use of simplified surface-runoff models may be an acceptable solution as they require fewer input data if compared to large datasets essential in more complex models (Jeon et al. 2014). The Soil Conservation Service Curve Number (CN) based models consider the main watershed characteristics, such as soil type and land use, while allowing the estimation of surface runoff from rainfall (USDA-NRCS 2004). Direct runoff is defined and may be relevant in the calibration of other parameters such as the initial abstractions relation $\left(\mathrm{Ia}=\varphi \mathrm{S}\right.$, being $\mathrm{I}_{\mathrm{a}}$ the initial abstraction, $S$ the maximum potential retention, and $\varphi$ a fraction of S). Although $\varphi$ is often set equal to 0.2 (USDA NRCS 2004), several authors suggest that it varies from location to location (Ling et al. 2019) and that such value may not be adequate for certain regions (Portela et al. 2000) as it tends to overestimate the initial rainfall losses or abstractions. This suggests that the calibration of that parameter can be of relevance when applying $\mathrm{CN}$ based models. For Portugal mainland, Correia (1984) concluded that the assumption of $\varphi=0.2$ was not verified, suggesting that it could be lower.

The main objective of this study, which is part of a broader work to characterise water availability, is to evaluate the sensitivity of a simplified precipitation-runoff model and explore possible relations between intrinsic watershed characteristics and the evaluated input parameters to define calibration functions for similar ungauged watersheds.

\section{Study area}

The study area is the southern region of Portugal, characterised by high seasonal variability of rainfall (Trigo and DaCamara 2000; Durão et al. 2010; Gassert et al. 2015) and prone to extended periods of drought (Santos et al. 2010), which are expected to become increasingly recurrent (Oliveira 2007). The region includes two of the most important Portuguese river basins, Guadiana and Sado, with the presence of major surface water storage infrastructures on which most economic activities depend.

The area is mainly composed of low permeability metamorphic and eruptive rocks (77\%) with permeable sedimentary and karstic formations mainly located near the south coastline. Water scarcity phenomena connected to seasonal tourism and agricultural pressures require a robust integrated and effective management of water resources (Portuguese Environmental Agency (APA) 2020). On the opposite way, the region is also prone to flash flood events (Ramos and Reis 2002), related to the low permeability rocks, coupled with intense and time-concentrated rainfall episodes.

Figure 1 shows the study area and the selected set of 22 watersheds, numbered from north to south. The selection of watersheds relied on the availability of surface flow data and that no surface water reservoirs existed when the river flow measurements were conducted (watersheds under natural conditions)

\section{Objectives and Methods \\ Sequential water budget model description}

The model used, BALSEQ, was developed by Lobo Ferreira (1981). It is one of the several daily sequential water budget models and has been widely applied, mainly for the evaluation of groundwater recharge, in Portugal in diverse hydrogeological settings - from sedimentary basins (Oliveira and Lobo Ferreira 1999; Leitão et al. 2001), to predominantly fractured lithologies (Oliveira et al. 1997) and volcanic regions (Novo et al. 1994) - but also in India (Chachadi et al. 2001; Chachadi et al. 2005) and Brazil (Leitão et al. 2017; Costa et al. 2019).

One of BALSEQs' main advantages is that it estimates a set of hydrological components using information that is usually easily available. BALSEQ inputs are daily rainfall (P), potential evapotranspiration (PET), Soil Conservation Service Curve Number $(\mathrm{CN})$ and the maximum amount of water available in the soil for evapotranspiration (AGUT). The main outputs are direct runoff $\left(\mathrm{E}_{\mathrm{d}}\right)$ and soil deep infiltration $\left(\mathrm{I}_{\mathrm{p}}\right)$. Considering a soil control volume, the model assumes that inflow water is exclusively due to the infiltration, given by rainfall minus direct runoff. The flow is purely vertical. Side outflow from the control volume and surface water extraction are not considered. Variables related to water fluxes are expressed in $\mathrm{mm}$. It uses the Soil Conservation Service (SCS) formulation to calculate direct runoff $\left(\mathrm{E}_{\mathrm{d}}\right)$, based on the $\mathrm{CN}$ parameter (USDA-NRCS 2004), according to the following equations:

$$
\begin{aligned}
& E_{d}=\frac{\left(P-I_{a}\right)^{2}}{\left(P-I_{a}\right)+S} \\
& C N=\frac{1000}{10+\frac{S}{25.4}} \Leftrightarrow S=\left(\frac{1000}{C N}-10\right) \cdot 25.4 \\
& I_{a}=\varphi S
\end{aligned}
$$

where $I_{a}$ are the initial abstractions $(\mathrm{mm}), S$ is the potential maximum retention $(\mathrm{mm})$ and $\varphi$ is the fraction of $S$, defined as 0.2 based on the study by the SCS of a set of watersheds in the USA. By combining equations (2) and (3) and introducing 


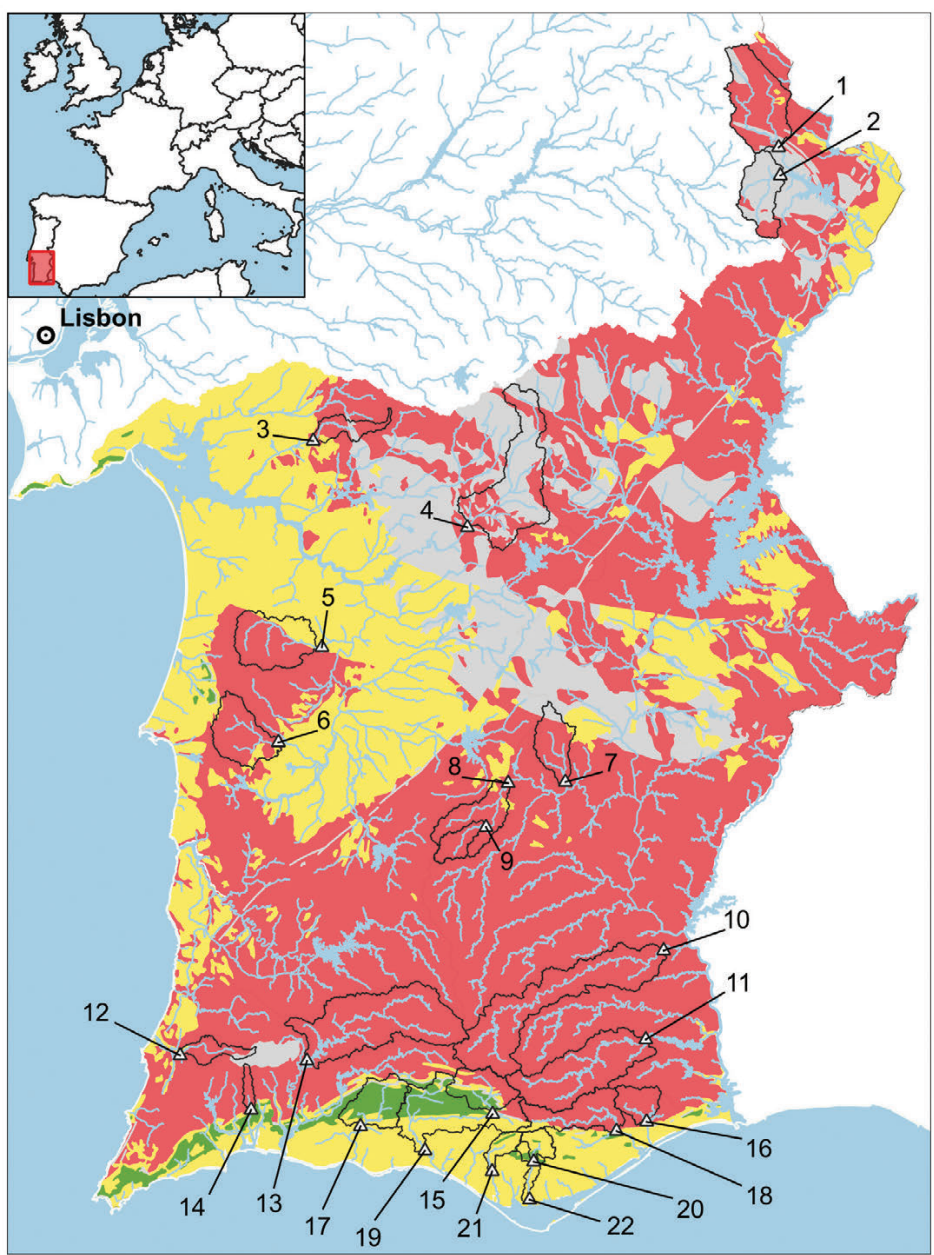

\begin{tabular}{ccccc}
\hline ID code & Official database code & Designation & X coord. & $Y$ coord. \\
\hline 1 & $19 \mathrm{~N} / 01 \mathrm{H}$ & Monte do Pisão & 74444.8 & -61660.2 \\
\hline 2 & $19 \mathrm{~N} / 02 \mathrm{H}$ & Ponte Algalé & 74811.6 & -67823.6 \\
\hline 3 & $22 \mathrm{G} / 02 \mathrm{H}$ & Herdade das Pancas & -28196.5 & -126301.4 \\
\hline 4 & $23 \mathrm{I} / 01 \mathrm{H}$ & Flor da Rosa & 5808.9 & -145344.3 \\
\hline 5 & $25 \mathrm{G} / 04 \mathrm{H}$ & Ponte de Vale Joana & -26265.9 & -171737.6 \\
\hline 6 & $26 \mathrm{~F} / 02 \mathrm{H}$ & Ponte São Domingos & -35869.1 & -192706.4 \\
\hline 7 & $26 \mathrm{~K} / 01 \mathrm{H}$ & Monte da Arregota & 27408.4 & -201420.4 \\
\hline 8 & $26 \mathrm{~J} / 01 \mathrm{H}$ & Albernoa & 14804.2 & -201687.3 \\
\hline 9 & $27 / / 01 \mathrm{H}$ & Entradas & 9922.8 & -211366.5 \\
\hline 10 & $28 \mathrm{~L} / 02 \mathrm{H}$ & Vascão & 49087.5 & -238540.8 \\
\hline 11 & $29 \mathrm{~L} / 01 \mathrm{H}$ & Monte dos Fortes & 45148.8 & -258127.7 \\
\hline 12 & $30 \mathrm{E} / 04 \mathrm{H}$ & Ponte Pereiro & -57545.8 & -261661.9 \\
\hline 13 & $30 \mathrm{G} / 01 \mathrm{H}$ & Monte dos Pachecos & -29573.6 & -262838.9 \\
\hline 14 & $30 \mathrm{~F} / 02 \mathrm{H}$ & Vidigal & -41885.7 & -273636.5 \\
\hline 15 & $30 \mathrm{l} / 05 \mathrm{HA}$ & Quinta Passagem & 11365.2 & -274580.1 \\
\hline 16 & $30 \mathrm{~L} / 02 \mathrm{H}$ & Curral de Boieiros & 45332.4 & -276255.7 \\
\hline 17 & $30 \mathrm{G} / 08 \mathrm{H}$ & Ponte Mesquita & -17755.4 & -277269.8 \\
\hline 18 & $31 \mathrm{~K} / 03 \mathrm{H}$ & Bodega & 38692.7 & -278296.7 \\
\hline 19 & $31 \mathrm{H} / 02 \mathrm{H}$ & Ponte Rodoviaria & -3546.9 & -282615.6 \\
\hline 20 & $31 \mathrm{~J} / 01 \mathrm{H}$ & Coiro da Burra & 20430 & -285074.6 \\
\hline 21 & $31 \mathrm{l} / 01 \mathrm{HA}$ & Sítio Igreja & 11265.4 & -287203.8 \\
\hline 22 & $31 \mathrm{~J} / 01 \mathrm{HA}$ & Rio Seco & 19533.2 & -293446.7 \\
\hline & & & &
\end{tabular}

Legend
$\Delta \quad$ Gauging stations
$\square$ Watersheds
$-\quad$ Rivers
Surface water bodies
Regional main lithologies
Sedimentary rocks
Metamorfic rocks
Eruptive rocks
Karstic areas

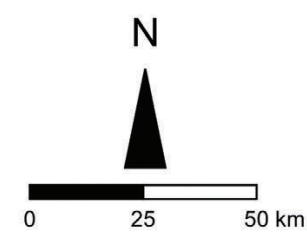

Source: PT 1:1 000000 geol. map (APA-Atlas Ambiente) Projection: ETRS 89 TM06 PT

Fig. 1 - Study area, schematic representation of the studied watersheds and numbering and identification of the corresponding river gauge stations.

Fig. 1 - Area di studio, rappresentazione schematica dei bacini idrografici studiati e numerazione e identificazione delle corrispondenti stazioni di sagoma fluviale.

the result achieved in equation (1) it is possible to address the variation of the generated direct runoff as a function of $\varphi$, as expressed by equation (4):

$$
E_{d}=\frac{25.4\left(\frac{P}{25.4}-\frac{1000 \varphi}{C N}+10 \varphi\right)^{2}}{\frac{P}{25.4}+\frac{1000-1000 \varphi}{C N}-10+10 \varphi}
$$

As $\varphi$ increases $I_{a}$ will also increase resulting in a decrease of $\mathrm{E}_{\mathrm{d}}$. Figure 2 shows the theoretical behaviour of the computed $\mathrm{E}_{\mathrm{d}}$ for different rainfall values and $\varphi$ for $\mathrm{CN}=80$.

The formulation for $\mathrm{E}_{\mathrm{d}}$ given by equation (4) was included in the BALSEQ model (Fig. 3), replacing the original formula defined by SCS. The daily deep infiltration $\left(\mathrm{I}_{\mathrm{p}}\right)$ is calculated by equation (5):

$$
I_{p}=P-E_{d}-A E T-\Delta A_{1}
$$

where AET is the actual evapotranspiration and $\Delta A_{1}$ is the variation of water within the control volume during each day. The difference between $\mathrm{P}$ and $\mathrm{E}_{\mathrm{d}}$ corresponds to the $\mathrm{I}_{\mathrm{s}}$ (surface infiltration), the amount of water that enters the soil control volume. Given that $\mathrm{CN}$ values are extracted for regular antecedent moisture conditions (AMC II) - which may not be the most adequate approach for the studied area given it often experiences long dry periods followed by intense rain episodes - the model was adjusted to consider dry (CNI) and wet (CNIII) antecedent conditions (Chow et al. 1988) equation (6) and (7).

$$
\begin{aligned}
& C N_{I}=\frac{4.2 C N_{I I}}{10-0.058 C N_{I I}} \\
& C N_{I I I}=\frac{23 C N_{I I}}{10+0.13 C N_{I I}}
\end{aligned}
$$

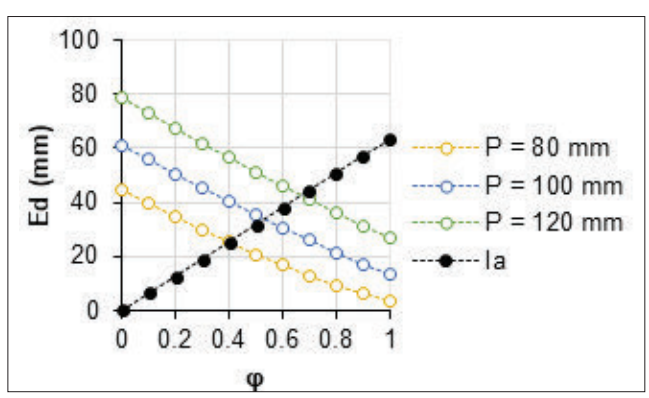

Fig. 2 - General variation of computed $E_{d}$ by changing rainfall and $\varphi$.

Fig. 2 - Variazione complessiva del $\mathrm{E}_{\mathrm{d}}$ calcolato a seconda delle variazioni delle precipitazioni e di $\varphi$. 


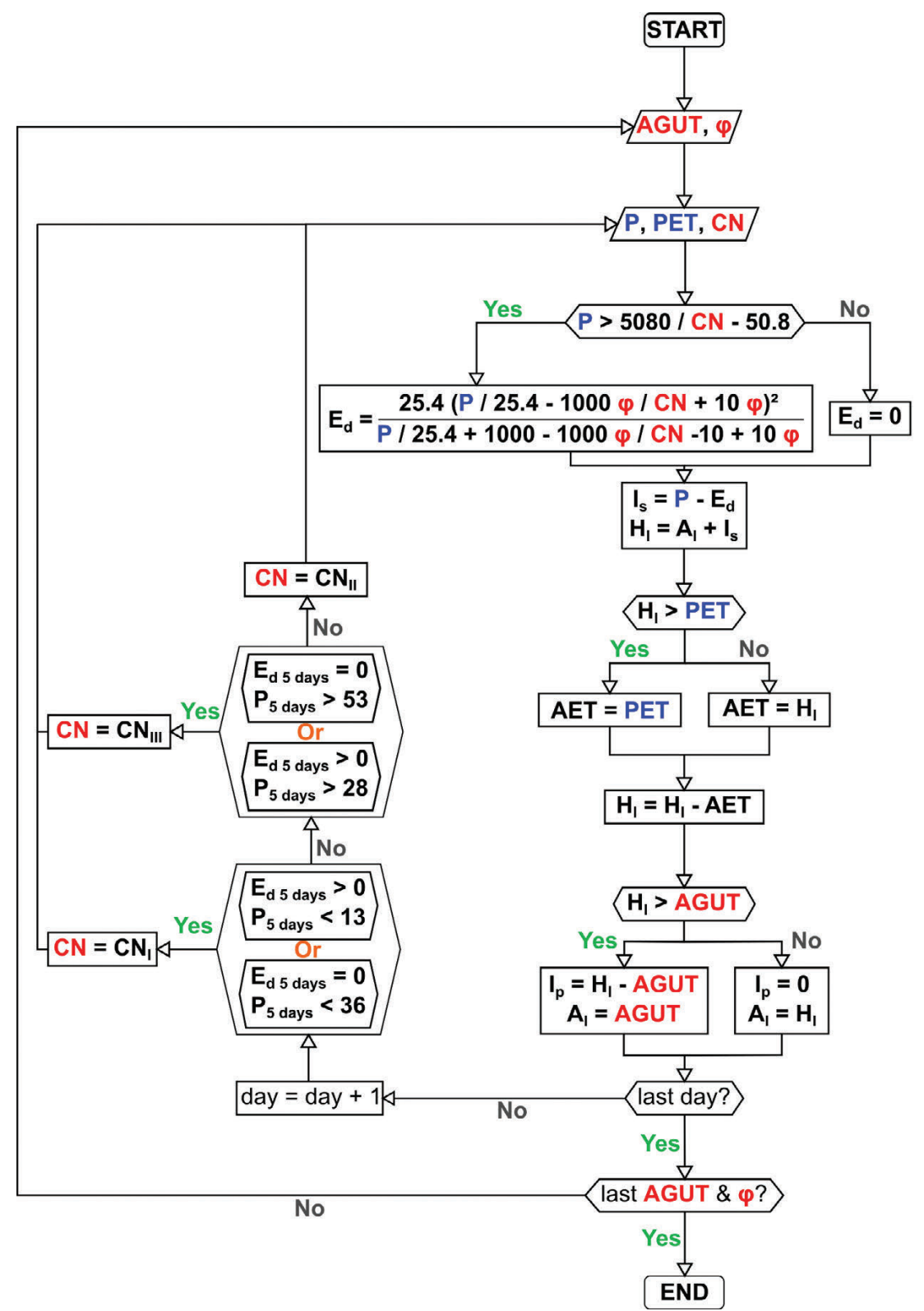

$\mathbf{P}=$ daily rainfall

PET = daily potential evapotranspiration

$\mathrm{CN}=\mathrm{SCS}$ curve number

$\varphi=$ fraction of initial abstractions

$E_{d}=$ direct runoff

$I_{s}=$ soil infiltration

$A_{1}=$ water stored in the soil at the end of the day

$\mathbf{H}_{\mathbf{1}}=$ water stored in the soil throughout the day

AET = actual evapotranspiration

AGUT = maximum amount of water in soil available for evapotranspiration

AGUT $=$ (fc - wp) $\mathbf{R d}$

fc $=$ soil field capacity

$\mathbf{w p}=$ wilting point

$\mathbf{R d}=$ root depth

$I_{p}=$ deep infiltration

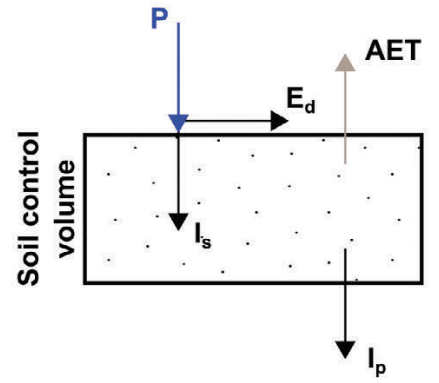

Note: all variables related to water fluxes are expressed in $\mathrm{mm}$

Fig. 3 - Approach implemented in adapted BALSEQ model.

Fig. 3 - Approccio implementato nel modello BALSEQ.

Figure 4 shows the behaviour of BALSEQs' main outputs - direct runoff, Ed, and deep infiltration, $I_{p}$ - for different values of AGUT and $\varphi$, using rainfall, evapotranspiration, and $\mathrm{CN}$ for the watershed of $9-$ Entradas. For the same rainfall episode, if $\varphi$ is increased, the $E_{d}$ decreases (Fig. 2) while the amount of water that enters the control volume increases. Since the AGUT parameter controls the amount of water that is retained in the soil, higher AGUT results in the decrease of the amount of water that exits the control volume to recharge the aquifer $\left(\mathrm{I}_{\mathrm{p}}\right)$.

The model was implemented in a Python 3 script and run at a daily scale starting at the beginning of each hydrological year-October $1^{\text {st }}$ - assuming that $A_{1}=0$.

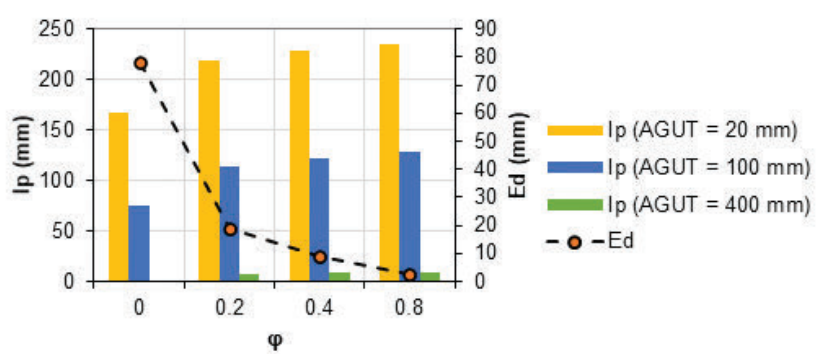

Fig. 4 - Variation of $E_{d}$ and $I_{p} B A L S E Q$ components for different inputs.

Fig. 4 - Variazione celle componenti BALSEQ $\mathrm{E}_{\mathrm{d}}$ ed $\mathrm{I}_{\mathrm{p}}$. 


\section{Preparation of input data and hydrogeological models}

The daily rainfall dataset was assembled from rainfall series collected and published by the Portuguese National Water Resources Information System (https://snirh.apambiente.pt/) for 191 rain gauge stations within the study area. A sub-set of stations was selected for each watershed, using proximity criteria, from which average rainfall series was computed using Inverse Distance Weighting (IDW) based on a $1 \mathrm{~km}$ cell-sized grid. The average PET series was generated using the Thiessen polygons method from a dataset assembled from data made available by regional agricultural authorities and the Portuguese Environmental Agency (Supplementary Materials, Tab. 5). The daily values of surface flow (SF) were extracted from the Portuguese National Water Resources Information System for each of the 22 selected watersheds.

The extension of assembled meteorological input series varied from 4 to 24 hydrological years depending on the length of surface flow (SF) dataset. Table 1 summarizes the studied watersheds characteristics, average meteorological data and SF, as well as a SF-Rainfall ratio. The stations used for generating rainfall, PET and SF series for each watershed are presented in Supplementary Materials (Tab. 6 to Tab. 13).

AGUT is computed based on three different parameters - soil field capacity (fc), wilting point (wp) and root depth (Rd) - associated with the soil use/occupation mapped by CORINE Land Cover Inventory (CLC, in https://land. copernicus.eu/pan-european/corine-land-cover) and soil type maps. Root depth, even in annual average terms, is, e.g., highly dependent not only on the vegetation type but also on pedologic or geologic characteristics; moreover, it changes seasonally with the vegetation natural cycles. It is, therefore, a parameter highly susceptible to calibration. Vermeulen et al. (1993), Oliveira et al. (1997) and Oliveira (2004/2006) established fc, wp and Rd for different types of soil and land use. An adaptation of $\mathrm{Rd}$ was conducted to adjust $\mathrm{Rd}$ to Lithosols $(100 \mathrm{~mm})$, in line with the pedologic characteristics of the study area.

$\mathrm{CN}$ was calculated based on the maps generated for southern Portugal presented in Martins et al. (2021), from which the soil and land use dataset was adopted to calculate AGUT. These maps resulted from the implementation of the method presented by Vermeulen et al. (1993) and adapted by Oliveira et al. (1997) and Oliveira (2004/2006), which assigned the $\mathrm{CN}$ value considering: (1) the soil type derived from the Portuguese soil classification maps and (2) the land-use description based on CLC. Spatial weighted AGUT (AGUTp) and $\mathrm{CN}$ (CNp), were calculated for each watershed (Tab. 1), i.e., a single average value computed from all AGUTs and $\mathrm{CNs}$ weighted by the area of occurrence.

To consider the effect of the exchanges that occur between surface and subsurface, simulations were conducted assuming different contributions of the deep infiltration, Ip, to the total computed flow $\left(\mathrm{E}_{\text {total }}=\mathrm{E}_{\mathrm{d}}+\mathrm{x} \% \mathrm{I}_{\mathrm{p}}\right.$, being $\mathrm{x}$ a percentage of $\mathrm{I}_{\mathrm{p}}$ ) considering different conceptual models (CM) based on hydrogeological characteristics (Fig. 5). After the recharge process, calculated with BALSEQ, it is assumed that the water will flow in the saturated zone and sometimes discharge to the surface. For the studied watersheds, this discharge may occur almost completely inside the watershed, in the case of underlying less permeable formations (fractured massifs), where $\mathrm{x} \% \mathrm{I}_{\mathrm{p}}$ assumes a value close to 100 , or, in the case of more permeable watersheds, may discharge outside the watershed limit, $\mathrm{x} \% \mathrm{I}_{\mathrm{p}}$ is closer to 0 .

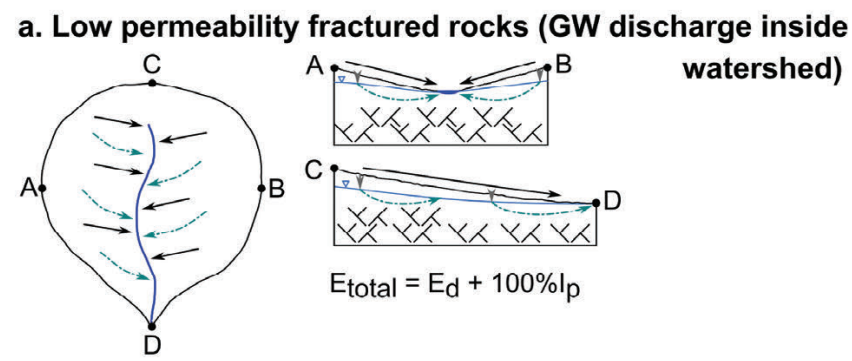

b. Sedimentary w/ partial GW discharge inside watershed

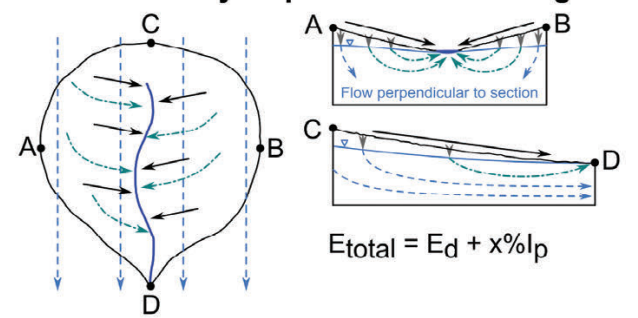

c. Sedimentary w/ GW discharge outside watershed

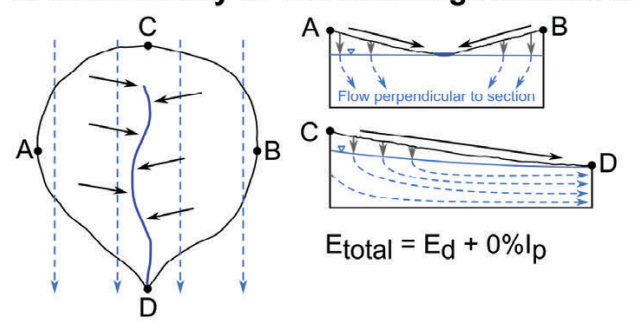

d. Karstic area w/ GW discharge outside watershed

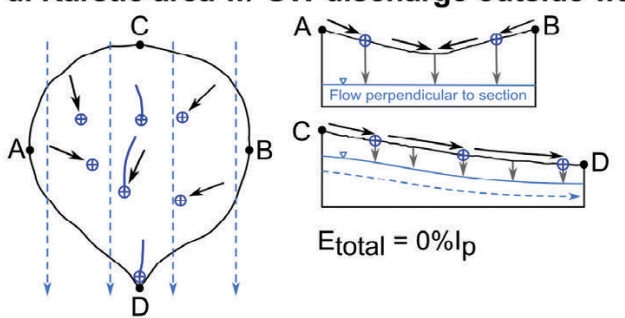

$$
\begin{aligned}
& \multicolumn{2}{l}{\text { LEGEND }} \\
& \oplus \quad \text { Karstic sinkhole } \\
& \longrightarrow \text { Deep GW flow } \\
& \longrightarrow \text { Direct runoff }\left(E_{d}\right) \\
& \downarrow \text { Deep infiltration }\left(I_{p}\right) \\
& \cdots \text { Return flow } \\
& \longrightarrow \text { Stream } \\
& \square \text { GW level } \\
& \nvdash \text { Low permeability area }
\end{aligned}
$$

Fig. 5 - Simplified schemes of watershed conceptual models under different hydrogeological constraints.

Fig. 5 - Schemi semplificati di modelli concettuali di spartiacque in base a vincoli idrogeologici differenti. 
Tab. 1 - BALSEQ input bydro-meteorological data.

Tab. 1 - Valori idrometereologici BALSEQ di input.

\begin{tabular}{|c|c|c|c|c|c|c|c|c|c|}
\hline Watershed & $\begin{array}{c}\text { Area } \\
\left(\mathrm{km}^{2}\right)\end{array}$ & $\begin{array}{c}\mathrm{P} \\
(\mathrm{mm} / \mathrm{y})\end{array}$ & $\begin{array}{c}\text { PET } \\
(\mathrm{mm} / \mathrm{y})\end{array}$ & $\begin{array}{c}\mathrm{SF} \\
(\mathrm{mm} / \mathrm{y})\end{array}$ & $\begin{array}{l}\text { SF-R } \\
\text { ratio }\end{array}$ & $\begin{array}{c}\text { Starting } \\
\text { year }\end{array}$ & \# of years & $\mathrm{CNp}$ & $\begin{array}{c}\text { AGUTp } \\
(\mathrm{mm})\end{array}$ \\
\hline 1 - Monte do Pisão & 227.5 & 812.7 & 1239.7 & 208.6 & $26 \%$ & 1983 & 7 & 74.5 & $314.7 *$ \\
\hline 2 - Ponte Algalé & 127.3 & 532.1 & 1100.7 & 74.7 & $14 \%$ & 1985 & 9 & 68.0 & $182.8 *$ \\
\hline 3 - Herdade das Pancas & 57.1 & 672.6 & 1224.8 & 172.9 & $26 \%$ & 1981 & 9 & 75.8 & $274.5 *$ \\
\hline 4 - Flor da Rosa & 330.1 & 695.4 & 1222.6 & 199.4 & $29 \%$ & 1941 & 24 & 75.2 & $134.9 *$ \\
\hline 5 - Ponte de Vale Joana & 180.0 & 532.8 & 1207.7 & 82.4 & $15 \%$ & 2001 & 7 & 74.8 & $129.0 * *$ \\
\hline 6 - Ponte São Domingos & 146.8 & 647.0 & 1297.7 & 164.3 & $25 \%$ & 1982 & 7 & 75.6 & $170.6 *$ \\
\hline 7 - Monte da Arregota & 98.4 & 524.5 & 1299.7 & 96.6 & $18 \%$ & 1981 & 9 & 81.0 & $240.6 *$ \\
\hline 8 - Albernoa & 169.9 & 508.8 & 1296.1 & 108.5 & $21 \%$ & 1970 & 21 & 83.7 & $136.1 *$ \\
\hline 9 - Entradas & 51.2 & 530.1 & 1298.7 & 123.0 & $23 \%$ & 1971 & 22 & 84.4 & $108.8 *$ \\
\hline 10 - Vascão & 409.0 & 716.8 & 1464.2 & 350.1 & $49 \%$ & 1960 & 14 & 78.1 & $8.1 *$ \\
\hline 11 - Monte dos Fortes & 283.2 & 839.2 & 1606.6 & 248.9 & $30 \%$ & 1980 & 13 & 77.9 & $0.5 *$ \\
\hline 12 - Ponte Pereiro & 50.0 & 718.3 & 1066.5 & 346.7 & $48 \%$ & 2001 & 6 & 78.1 & $284.0 * *$ \\
\hline 13 - Monte dos Pachecos & 394.2 & 752.0 & 1510.2 & 324.8 & $43 \%$ & 1962 & 21 & 78.6 & $7.5 *$ \\
\hline 14 - Vidigal & 18.8 & 663.9 & 1496.8 & 167.9 & $25 \%$ & 1998 & 9 & 83.1 & $223.3 *$ \\
\hline 15 - Quinta Passagem & 100.5 & 708.3 & 1545.8 & 185.3 & $26 \%$ & 2000 & 7 & 79.1 & $47.2 * *$ \\
\hline 16 - Curral de Boieiros & 61.4 & 747.9 & 1546.7 & 256.2 & $34 \%$ & 1984 & 11 & 77.7 & $3.4 *$ \\
\hline 17 - Ponte Mesquita & 117.6 & 798.9 & 1559.8 & 34.5 & $4 \%$ & 1984 & 6 & 83.6 & $147.0 *$ \\
\hline 18 - Bodega & 133.2 & 744.8 & 1604.3 & 229.7 & $31 \%$ & 1975 & 14 & 78.2 & $8.2 *$ \\
\hline 19 - Ponte Rodoviaria & 325.4 & 725.1 & 1524.0 & 90.4 & $12 \%$ & 1980 & 14 & 80.5 & $82.5 *$ \\
\hline 20 - Coiro da Burra & 35.8 & 834.3 & 1613.2 & 236.7 & $28 \%$ & 1985 & 4 & 81.1 & $124.3 *$ \\
\hline 21 - Sítio Igreja & 33.9 & 679.3 & 1612.9 & 36.9 & $5 \%$ & 1996 & 9 & 81.3 & $130.2 *$ \\
\hline 22 - Rio Seco & 63.5 & 728.0 & 1609.8 & 97.9 & $13 \%$ & 1995 & 12 & 82.3 & $141.7 *$ \\
\hline & \multicolumn{9}{|c|}{$\begin{array}{l}\text { P - rainfall (precipitazioni); PET - potential evapotranspiration (evaporazione potenziale); SF - surface flow (flusso superficiale) } \\
\text { AGUTp - spatial weighted average AGUT (media spaziale ponderata di AGUT); CNp - spatial weighted average CN (medic } \\
\text { spaziale pondeata di CN); SF-R ratio - Surface Flow-Rainfall ratio (media flusso superficiale-pioggia) } \\
\text { * AGUTp computed based in } 1990 \text { CORINE Land Cover Inventory version; } \\
\text { ** AGUTp computed based in } 2018 \text { CORINE Land Cover Inventory version. }\end{array}$} \\
\hline
\end{tabular}

\section{Sensitivity analysis procedures}

Two different simulation procedures were used for the evaluation of the model sensitivity based on the variation of parameters (Tab. 2). The first procedure aimed to understand the impact of variation of $\varphi$ using fixed spatial weighted $\mathrm{CN}(\mathrm{CNp})$ and fixed spatial weighted AGUT (AGUTp), with different $\mathrm{x} \% \mathrm{Ip}$ considered in the calculation of $\mathrm{E}_{\text {total }}$.
Five $I_{p}$ percentages were used $0 \%$ (i.e., no deep infiltration), $20 \%, 50 \%, 80 \%$ and $100 \%$, and 21 values of $\varphi$ (from 0 to 0.8 with an increment of 0.04 ). The second procedure aimed to understand the coupled impact of varying AGUT and $\varphi$ using fixed $\mathrm{CNp}$. This procedure only considered three different percentages of Ip: $20 \%, 50 \%$ and $100 \%$. Sensitivity to different $\mathrm{CN}$ was not studied as it is assumed that it is supported by empirical data (Ponce et al. 1996).

Tab. 2 - BALSEQ inputs considered in the sensitivity analysis conducted.

Tab. 2 - Valori BALSEQ di input considerati per l'analisi di sensitività.

\begin{tabular}{|c|c|c|c|c|c|}
\hline \multirow{2}{*}{ Sensitivity analysis designation } & \multicolumn{4}{|c|}{ Variables considered in simulations } & \multirow{2}{*}{$\begin{array}{l}\text { \# of simulations conducted } \\
\text { for each watershed }\end{array}$} \\
\hline & $\mathrm{CN}$ & $\varphi$ & AGUT (mm) & $\mathbf{x} \% \mathbf{I}_{\mathrm{p}}$ & \\
\hline $\begin{array}{l}\text { [1] Sensitivity of the parameters } \varphi \\
\text { and percentage of } I_{p} \text { for fixed CNp } \\
\text { and AGUTp }\end{array}$ & \multirow{2}{*}{$\begin{array}{c}\mathrm{CNp} \\
{[1]}\end{array}$} & \multirow{2}{*}{$\begin{array}{c}{[0-0.8] *} \\
\Delta=0.04 \\
{[21]}\end{array}$} & $\begin{array}{c}\text { AGUTp } \\
{[1]}\end{array}$ & $\begin{array}{c}0,20,50,80,100 * \\
{[5]}\end{array}$ & 105 \\
\hline $\begin{array}{l}{[2] \text { Sensitivity of the parameters }} \\
\varphi \text {, percentage of } I_{p} \text { and AGUT for } \\
\text { fixed } \mathrm{CNp}\end{array}$ & & & $\begin{array}{c}{[0-500] *} \\
\Delta=20 \\
{[25]}\end{array}$ & $\begin{array}{c}20,50,100 * \\
{[3]}\end{array}$ & 1575 \\
\hline
\end{tabular}


The adjustment between computed surface flow $\left(\mathrm{E}_{\text {total }}\right)$ and measured surface flow (SF) was evaluated using the NashSutcliffe model efficiency coefficient, computed by equation (8):

$$
N S E=1-\frac{\sum_{i=1}^{n}\left(X_{i}^{o b s}-X_{i}^{s i m}\right)^{2}}{\sum_{i=1}^{n}\left(X_{i}^{o b s}-X^{\text {mean }}\right)^{2}}
$$

where $\mathrm{n}$ is the number of observations, $\mathrm{X}_{\mathrm{i}}{ }^{\text {obs }}$ is the ith observed/measured value, $\mathrm{X}_{\mathrm{i}}^{\text {sim }}$ is the $\mathrm{i}^{\text {th }}$ simulated/calculated value and $\mathrm{X}^{\text {mean }}$ is the mean of the observed data. The NSE ranges between $\infty$ and 1 (1 corresponds to the better adjustment and model performance). NSE $<=0$ means that the mean observed value is a better predictor than the simulated value, meaning unacceptable performance (Moriasi et al. 2007). Other measures of accuracy were computed for the performance analysis of all watersheds, specifically, the root mean square error, RMSE, and the percentage of bias, PBIAS (Moriasi et al. 2015; Hofstra et al. 2008). The analysis of the results showed that RMSE variation for different pairs of AGUT and $\varphi$ was similar to the one of NSE, as exemplified in the heatmaps of Figure 16 included in Supplementary Materials based on 22 - Rio Seco watershed and $\mathrm{I}_{\mathrm{p}} 50 \%$. Although the evaluation of PBIAS is not directly comparable with the one of the other two measures, the PBIAS of the best-coupled values of AGUT and $\varphi$ proved to be acceptable, i.e., within a narrow range of variation around 0 (Fig. 16). However, only the results from NSE are shown as it provides a precise interpretable scale for characterizing the behaviour of the models (best performance for values of NSE between 1 and 0.5$)$.

\section{Impact of using the spatial weighted CN (CNp)}

Computation of $\mathrm{E}_{\mathrm{d}}$ using spatial weighted $\mathrm{CN}$ of the watershed instead of calculating $E_{d}$ for each association of $\mathrm{CN} / \mathrm{AGUT}$ and averaging the $\mathrm{E}_{\mathrm{d}}$ for the area of the watershed can result in the underestimation of the average of $E_{d}$, due to the non-linearity of the SCS Direct Runoff equation (Oliveira 2004, 2006; Beven 2012). Errors can result from the simplification of adopting a spatial weighted $\mathrm{CN}$ in the simulations conducted in each watershed. The two approaches were applied to 9 - Entradas watershed: (1) Direct runoff from spatial weighted $\mathrm{CN}$ (Avg. CN) and (2) spatial weighted direct runoff from each CN/AGUT (Avg. $\mathrm{E}_{\mathrm{d}}$ ). Figure 6 shows monthly and yearly results, confirming that in the first approach $E_{d}$ is slightly underestimated, with an average difference between the computed $\mathrm{E}_{\mathrm{d}}$ of $5 \%$ between the approaches and a coefficient of correlation, r, of 0.9998 and 0.9994 for monthly and yearly results, respectively. It was therefore assumed that it is acceptable to use the average $\mathrm{CN}$.

\section{Results and Discussion \\ Hydrogeological conceptual models of the studied watersheds}

The hydrological behaviour of the watersheds in terms of surface-subsurface water fluxes is influenced by several factors.
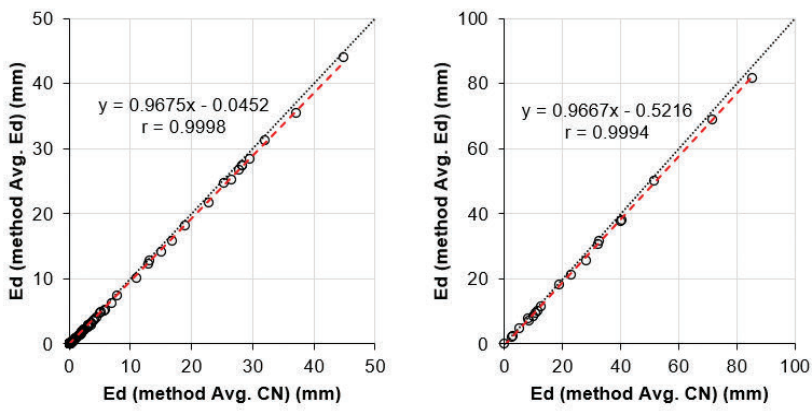

Fig. 6 - Monthly (left) and yearly (right) computed $E_{d}$ resulting from Avg. $E_{d}$ and Avg CN computation methods. $r$ is the coefficient of correlation.

Fig. $6-\mathrm{E}_{\mathrm{d}}$ calcolato mensilmente (sinistra) e annualmente (destra) calcolata risultante da Avg. Metodi di calcolo $E_{d}$ e Avg $\mathrm{CN}$. $r$ è il coefficiente di correlazione.

An unaccounted fraction of the rainfall that occurs in the basin may be lost to more permeable layers, particularly in karstic areas, which is a common occurrence in the most southern part of the study area, resulting in discharges outside watershed bounds. Those losses may explain the poor adjustment of the model results to the measured flow data, considering the previous assumption that at some point in the watershed the $I_{p}$ calculated will be added to the $E_{d}$ to calculate total flow $\left(\mathrm{E}_{\text {total }}\right)$. This may be significant if, e.g., the major upstream area of the watershed is mostly composed of rocks with low permeability, with good capacity to generate direct runoff but weak infiltration capacity, and transits downstream to more permeable or fractured areas, where point $I_{p}$ will have a small contribution in the $E_{\text {total }}$. This assumption may also account for possible transfers between neighbouring watersheds through shared fracture systems or increased permeability formations. It is important to consider this mixed hydrogeological behaviour within each watershed, where different $\mathrm{I}_{\mathrm{p}}$ must be considered in the conceptual model to calculate $\mathrm{E}_{\text {total }}$.

Ultimately, the dominant lithologies in each watershed are considered one of the main controllers of the hydrogeological behaviour and were identified for each watershed based on the 1:1 000000 geological map (Fig. 1). A lithology is considered dominant if it covers at least $20 \%$ of the area. The watersheds were classified by 4 categories presented in Table 3 related to the conceptual models (CM) considered in Figure 5.

\section{Sensitivity of the parameters $\varphi$ and percentage of $I_{p}$ for fixed CNp and AGUTp}

The results of this first set of simulations, conducted with AGUTp and $\mathrm{CNp}$ and variable percentage of $\mathrm{I}_{\mathrm{p}}$ and different values of $\varphi$, are presented in Table 3 and Supplementary Materials (Fig. 17 and Fig. 18). The most adequate value of $\varphi$ was extracted based on the NSE computed for monthly data.

Considering the CM-a group, eleven watersheds showed better adjustments for $100 \% \mathrm{I}_{\mathrm{p}}$, in consonance with the established model, and two showed better adjustments for $80 \% \mathrm{I}_{\mathrm{p}}$. The watershed $11-$ Monte dos Fortes (CM-a) showed better adjustment for $20 \% \mathrm{I}_{\mathrm{p}}$, while 16 - Curral de Boieiros $(\mathrm{CM}-\mathrm{a})$ and 18 - Bodega $(\mathrm{CM}-\mathrm{a})$ for $50 \% \mathrm{I}_{\mathrm{p}}$. In the CM-a 


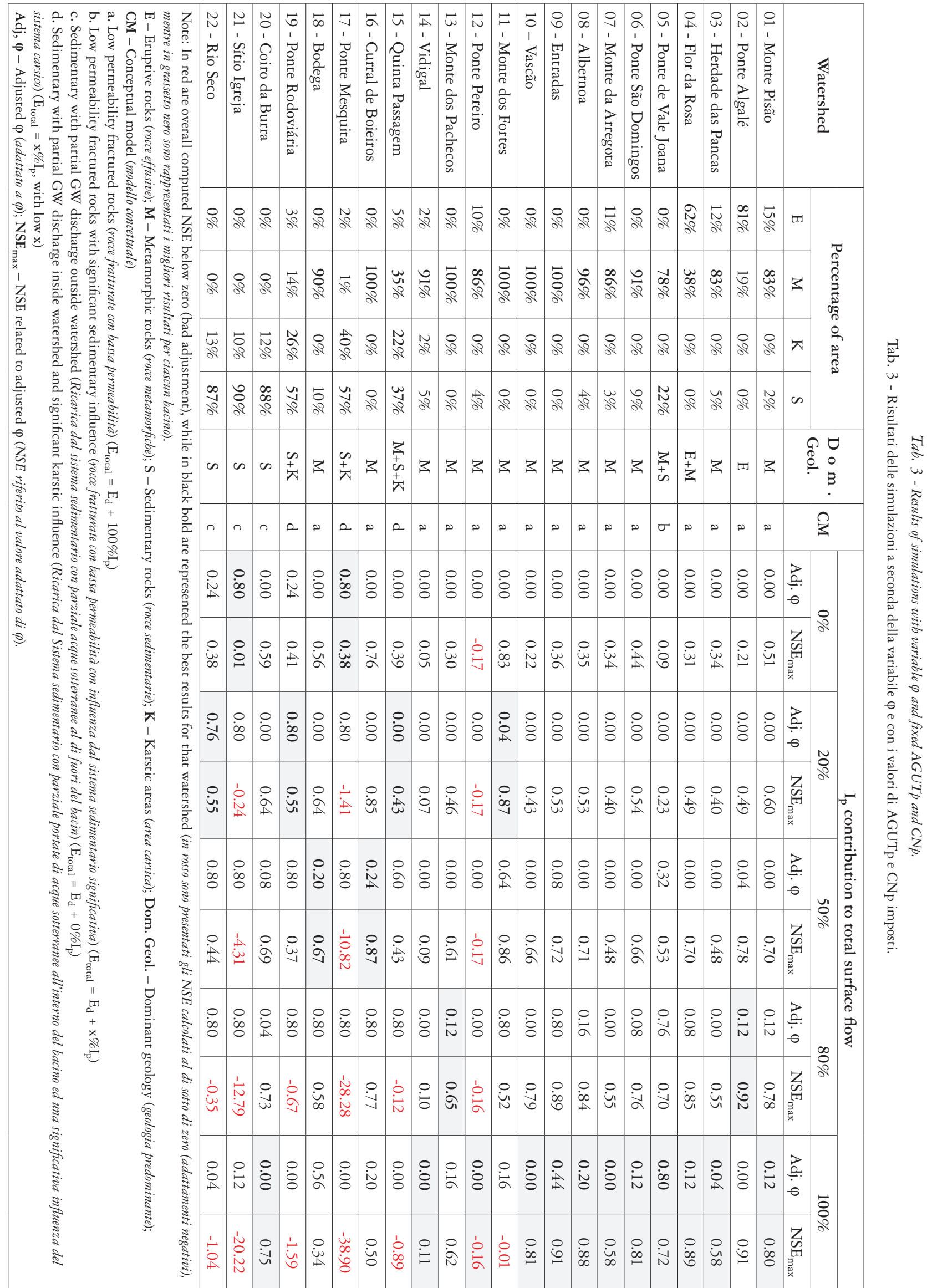


group, eleven watersheds resulted in adjusted $\varphi<0.2$ and four with values varying between 0.2 and 0.44 . In CM-b the better adjustment was observed for maximum $\varphi(0.8)$ and $100 \% \mathrm{I}_{\mathrm{p}}$.

In the three predominantly sedimentary watersheds (CMc), 21 - Sítio Igreja showed better adjustment for $0 \% \mathrm{I}_{\mathrm{p}}$, 22 - Rio Seco for $20 \% \mathrm{I}_{\mathrm{p}}$ and 20 - Coiro da Burra $80 \% \mathrm{I}_{\mathrm{p}}$, with adjusted $\varphi$ varying from 0.04 (20 - Coiro da Burra) to 0.8 (21 - Sítio Igreja). It is not clear how to derive a specific $I_{p}$ for this group, from which the hydraulic heterogeneity of the sedimentary rocks can result in different behaviour in terms of infiltration.

For CM-d watersheds, 17 - Ponte Mesquita showed better adjustment for $0 \% \mathrm{I}_{\mathrm{p}}(\varphi=0.8)$ and 15 - Quinta Passagem $(\varphi=0)$ and 19 - Ponte Rodoviária $(\varphi=0.8)$ for $20 \% \mathrm{I}_{\mathrm{p}}$.

12 - Ponte Pereiro (CM-a) showed NSE < 0 for all simulations and 17 - Ponte Mesquita (CM-d) followed by 21 - Sítio Igreja (CM-c) showed the worst results for NSE (-38.9 for $100 \%$ and -20.22 for $100 \%$, respectively).

Figure 7 compares average $\mathrm{E}_{\text {total }}$ and $\mathrm{E}_{\mathrm{d}}$ by measured surface flow, by watershed, for the more adequate percentages of $I_{p}$ given the established conceptual model (Tab. 3) $-\mathrm{a}=100 \% \mathrm{I}_{\mathrm{p}}$, $\mathrm{b}=80 \% \mathrm{I}_{\mathrm{p}}, \mathrm{c}=0 \% \mathrm{I}_{\mathrm{p}}$ and $\mathrm{d}=20 \% \mathrm{I}_{\mathrm{p}}$. For all watersheds and particularly for CM-a it is possible to observe the increase of $r$ computed between $\mathrm{E}_{\mathrm{d}}$ and $\mathrm{E}_{\text {total }}$ confirming the importance of the $I_{p}$ component to the total surface flow budget. That is similar to the CM-d group, in line with the established assumptions of the conceptual model. It must be noted that both CM-c and CM-d include a small number of watersheds not allowing the extraction of relevant correlation.

Adjusted $\varphi$ was plotted against CNp, AGUTp and yearly average rainfall to evaluate possible relations that may allow extrapolating to other watersheds - Supplementary Materials, Fig. 19a to Fig. 19c, respectively - and no relations were detected $(r<0.7)$.

\section{Sensitivity of the parameters $\varphi$, percentage of $I_{p}$ and AGUT for fixed CNp}

Concerning this sensitivity analysis, we opted to use three percentages of $\mathrm{I}_{\mathrm{p}}$ to (1) assume that at least $20 \%$ of the SF corresponds to $I_{p}$, following the premise that baseflow receives an important contribution from groundwater which is common in semi-arid areas and (2) reduce the number of simulations to be conducted.

Table 4 summarizes the results of the conducted simulations, presenting the pair of parameters (optimized AGUT AGUTo - and adjusted $\varphi$ ) for each $I_{p}$ that showed the best adjustment considering the maximum computed NSE for the monthly data. Figure 8 compares the computed AGUTo with AGUTp by watershed and represents the distribution of the adjusted $\varphi$ parameter. All results for the conducted simulations, including spatial distribution, are presented in the Supplementary Materials section (Fig. 20 to Fig. 33).

The optimized AGUT (AGUTo) is generally lower for CM-a and CM-b when compared with CM-c and CM-b. For CM-a and CM-b the expected increase in AGUTo as a result of increasing $\mathrm{I}_{\mathrm{p}}$ is lower if compared with CM-c and CM-d. This confirms the assumptions of the established conceptual models, considering that increased AGUTo results in lower $I_{p}$, which in predominantly sedimentary watersheds (CM-c) and watersheds with a significant presence of karstic areas (CM-d) the discharge may occur outside the watershed bounds (hence, the lower contribution of the $\mathrm{I}_{\mathrm{p}}$ in the $\mathrm{E}_{\text {total }}$ ). Considering the model used, lower AGUTo means less water stored in the soil and higher $\mathrm{I}_{\mathrm{p}}$. This is coherent with the assumption that in watersheds with low permeability rocks (CM-a and CM-b), higher $I_{p}$ is relevant in $E_{\text {total }}$, even if a different percentage of $I_{p}$ may have to be considered if other rocks may influence the infiltration. This is the case of CM-b (5 - Ponte de Vale Joana) which has $>20 \%$ of the area composed of sedimentary rocks, therefore the more adequate $\mathrm{I}_{\mathrm{p}}$ may be lower than $100 \%$. Some exceptions are observed within the CM groups. CM-a, 11 - Monte dos Fortes shows a relatively high AGUTo (400 $\mathrm{mm}$ ) for $100 \% \mathrm{I}_{\mathrm{p}}$. In CM-c, 20 - Coiro da Burra shows lower AGUTo for different $I_{p}$ if compared with other watersheds in the same group. This may be associated with increased average yearly rainfall and lower SF, having the higher SFRainfall ratio in the group.

In CM-d, 17 - Ponte Mesquita presents the better adjustment for the highest AGUTo considered $(500 \mathrm{~mm})$, having the lowest SF-Rainfall ratio of the dataset. Concerning CMs, in CM-a, for $100 \% \mathrm{I}_{\mathrm{p}}$, the adjusted $\varphi$ is lower than 0.24 ,
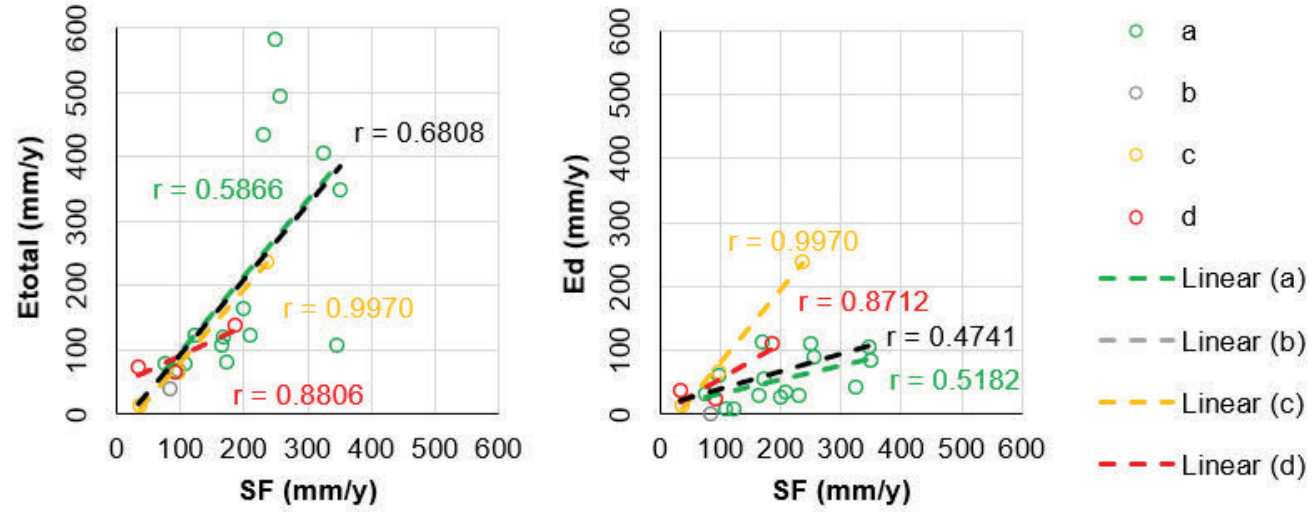

Fig. 7 - Computed $E_{\text {total }}$ (left) and $E_{d}($ right) vs measured surface flow (SF) for different $I_{p}$. Fig. 7 - Valori calcolati $\mathrm{E}_{\text {total }}$ (sinistra) e $\mathrm{E}_{\mathrm{d}}$ (destra) confrontate con il flusso superficiale misurato (SF) per diversi valori di $\mathrm{I}_{\mathrm{p}}$. 
Tab. 4 - Results of simulations with variable $\varphi$ and AGUT and static CNp.

Tab. 4 - Risultati delle simulazioni con $\varphi$ variabile e AGUT e CNp statico.

\begin{tabular}{|c|c|c|c|c|c|c|c|c|c|c|c|}
\hline \multirow{2}{*}{ Watershed } & \multirow{2}{*}{$\mathrm{CM}$} & \multirow{2}{*}{ AGUTp } & \multicolumn{3}{|c|}{$20 \% \mathrm{I}_{\mathrm{p}}$} & \multicolumn{3}{|c|}{$50 \% \mathrm{I}_{\mathrm{p}}$} & \multicolumn{3}{|c|}{$100 \% \mathrm{I}_{\mathrm{p}}$} \\
\hline & & & AGUTo & Adj. $\varphi$ & $\mathrm{NSE}_{\max }$ & AGUTo & Adj. $\varphi$ & $\mathrm{NSE}_{\max }$ & AGUTo & Adj. $\varphi$ & $\mathrm{NSE}_{\max }$ \\
\hline 1 - Monte do Pisão & $\mathrm{a}$ & 314.70 & 160 & 0.00 & 0.74 & 180 & 0.16 & 0.86 & 280 & 0.00 & 0.84 \\
\hline 2 - Ponte Algalé & $\mathrm{a}$ & 182.80 & 100 & 0.00 & 0.55 & 140 & 0.00 & 0.85 & 200 & 0.00 & 0.92 \\
\hline 3 - Herdade das Pancas & $\mathrm{a}$ & 274.50 & 100 & 0.00 & 0.57 & 120 & 0.00 & 0.79 & 160 & 0.48 & 0.93 \\
\hline 4 - Flor da Rosa & $\mathrm{a}$ & 134.90 & 80 & 0.00 & 0.52 & 100 & 0.00 & 0.74 & 140 & 0.24 & 0.89 \\
\hline 5 - Ponte de Vale Joana & $\mathrm{b}$ & 129.00 & 80 & 0.00 & 0.33 & 80 & 0.80 & 0.62 & 120 & 0.80 & 0.73 \\
\hline 6 - Ponte São Domingos & $\mathrm{a}$ & 170.60 & 80 & 0.00 & 0.62 & 100 & 0.00 & 0.78 & 140 & 0.08 & 0.86 \\
\hline 7 - Monte da Arregota & $\mathrm{a}$ & 240.60 & 60 & 0.00 & 0.56 & 80 & 0.00 & 0.77 & 100 & 0.04 & 0.84 \\
\hline 8 - Albernoa & $\mathrm{a}$ & 136.10 & 60 & 0.00 & 0.6 & 80 & 0.00 & 0.82 & 100 & 0.08 & 0.94 \\
\hline 9 - Entradas & $\mathrm{a}$ & 108.80 & 60 & 0.00 & 0.55 & 80 & 0.04 & 0.77 & 100 & 0.24 & 0.91 \\
\hline 10 - Vascão & $\mathrm{a}$ & 8.10 & 20 & 0.00 & 0.41 & 20 & 0.00 & 0.64 & 40 & 0.00 & 0.83 \\
\hline 11 - Monte dos Fortes & $\mathrm{a}$ & 0.50 & 100 & 0.00 & 0.9 & 120 & 0.12 & 0.94 & 400 & 0.00 & 0.88 \\
\hline 12 - Ponte Pereiro & $\mathrm{a}$ & 284.00 & 20 & 0.00 & -0.04 & 20 & 0.00 & 0.07 & 80 & 0.00 & 0.11 \\
\hline 13 - Monte dos Pachecos & $\mathrm{a}$ & 7.50 & 20 & 0.00 & 0.45 & 80 & 0.00 & 0.62 & 100 & 0.04 & 0.8 \\
\hline 14 - Vidigal & $\mathrm{a}$ & 223.30 & 100 & 0.00 & 0.15 & 100 & 0.80 & 0.32 & 140 & 0.24 & 0.34 \\
\hline 15 - Quinta Passagem & $\mathrm{d}$ & 47.20 & 100 & 0.00 & 0.49 & 260 & 0.00 & 0.55 & 300 & 0.00 & 0.6 \\
\hline 16 - Curral de Boieiros & $\mathrm{a}$ & 3.40 & 20 & 0.00 & 0.84 & 60 & 0.00 & 0.89 & 80 & 0.04 & 0.81 \\
\hline 17 - Ponte Mesquita & $\mathrm{d}$ & 147.00 & 500 & 0.80 & 0.47 & 500 & 0.80 & 0.09 & 500 & 0.72 & -1.89 \\
\hline 18 - Bodega & $\mathrm{a}$ & 8.20 & 80 & 0.00 & 0.67 & 100 & 0.04 & 0.78 & 140 & 0.80 & 0.87 \\
\hline 19 - Ponte Rodoviária & $\mathrm{d}$ & 82.50 & 180 & 0.60 & 0.62 & 280 & 0.80 & 0.85 & 400 & 0.80 & 0.75 \\
\hline 20 - Coiro da Burra & $\mathrm{c}$ & 124.30 & 160 & 0.08 & 0.64 & 180 & 0.20 & 0.73 & 220 & 0.72 & 0.89 \\
\hline 21 - Sítio Igreja & $\mathrm{C}$ & 130.20 & 240 & 0.80 & 0.22 & 500 & 0.80 & 0.02 & 500 & 0.80 & -0.19 \\
\hline 22 - Rio Seco & c & 141.70 & 280 & 0.44 & 0.58 & 320 & 0.72 & 0.73 & 500 & 0.52 & 0.64 \\
\hline
\end{tabular}

with exception of 3 - Herdade de Pancas. This watershed shows no substantial difference in terms of dominant lithologies, rainfall or SF in comparison with other watersheds in the same group and, shows similar NSE values for a broad spectrum of $\varphi$ (Supplementary Materials - Fig. 21).

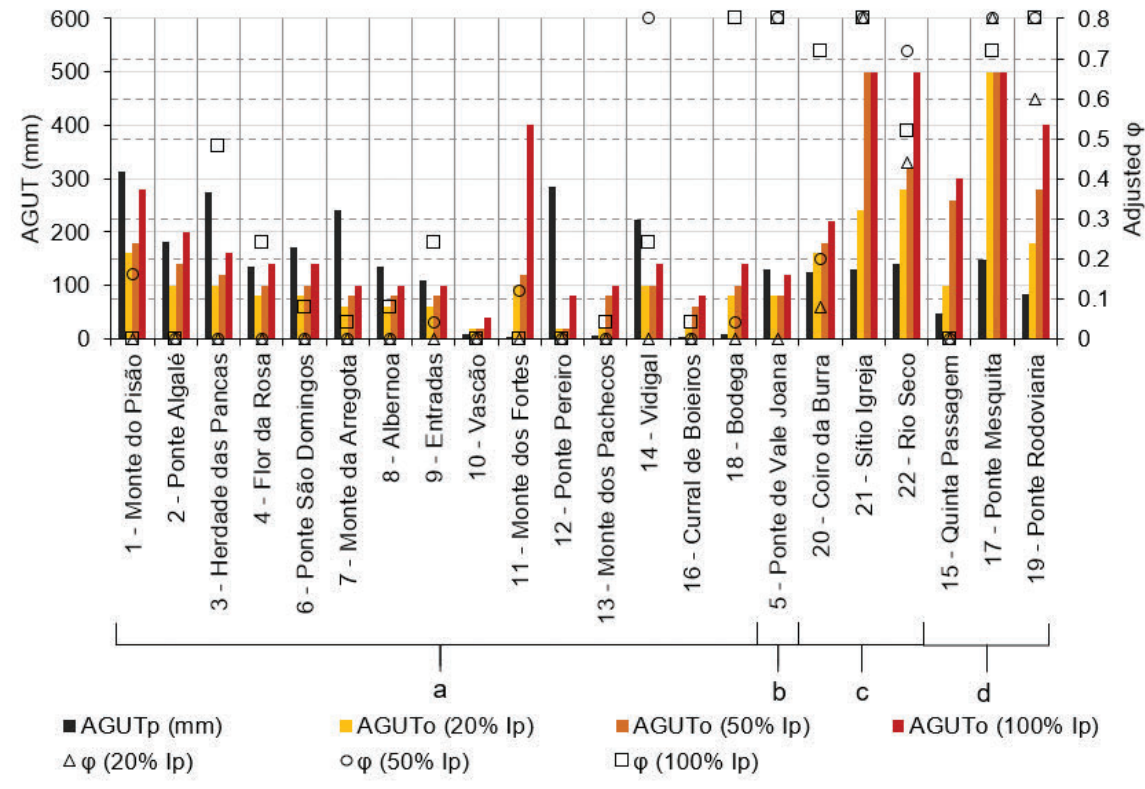

Fig. 8 - Results of simulations with variable $\varphi, I_{p}$ and AGUT and static CNp.

Fig. 8 - Risultati delle simulazioni a seconda delle variabili $\varphi$, $\mathrm{I}_{\mathrm{p}}$ e AGUT e CNp statico. 
The majority of watersheds show acceptable adjustment, with exception of 17 - Ponte Mesquita and 21 - Sítio Igreja having low NSE and, as expected, with better adjustments if compared with previous sensitivity analysis.

The measured yearly surface flow (SF) is compared with $\mathrm{E}_{\text {total }}$ in Figure 9, using adjusted $\varphi$ and AGUTo for each watershed for the preestablished percentage of $I_{p}$ for the conceptual model where each watershed was grouped $\left(\mathrm{a}=100 \% \mathrm{I}_{\mathrm{p}}\right.$, $c=20 \% I_{p}$ and $\left.d=50 \% I_{p}\right)$. Although an acceptable coefficient of correlation ( $r=>0.7)$ is observed for all watersheds and each $\mathrm{CM}$, achieving better results if compared with the previous sensitivity analysis (Fig. 7), it must be noted that BALSEQ generally overestimates $\mathrm{E}_{\text {total }}$ when analysing the results at this time scale.

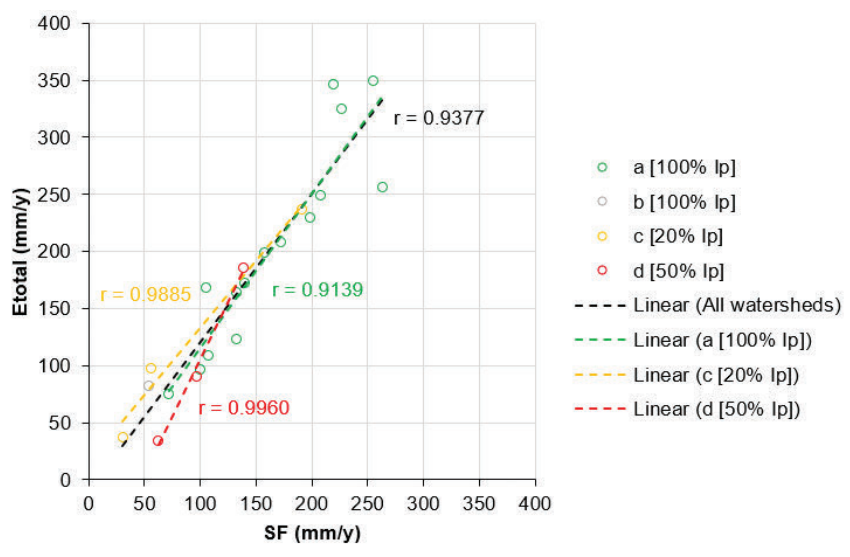

Fig. 9 - Computed $E_{\text {total }}$ vs measured surface flow (SF) for different $I_{p}$.

Fig. 9 - Valore di $\mathrm{E}_{\text {total }}$ calcolato confrontato con il flusso superficiale misurato (SF) per diversi valori di $\mathrm{I}_{\mathrm{p}}$.

Possible relations were explored between watershed characteristics: average annual rainfall vs adjusted $\varphi$, average annual rainfall vs AGUTo, CNp vs adjusted $\varphi$ and AGUTo vs AGUTp - Supplementary Materials, Fig. 34 a to Fig. 34d, respectively. No clear relationship can be attained due to the low correlation (CM-a) and a low number of watersheds in CM groups (CM-c and CM-d). In AGUTo vs AGUTp for CM-a, 11 - Monte dos Fortes was excluded which increased correlation but did not allow to achieve significance $(r<0.7)$.

\section{Detailed analysis of the BALSEQ response for the watersheds with the best and the worst adjustments for adjusted $\varphi$ and AGUTO simulations}

Looking into the results in detail, 11 - Monte dos Fortes had the best adjustment in the dataset $\left(\mathrm{NSE}_{\max }=0.94\right.$ for AGUTo $=120 \mathrm{~mm}$ and $\varphi=0.12$ ) while 17 - Ponte Mesquita showed the worst results $\left(\mathrm{NSE}_{\max }=-1,89\right.$, for $\mathrm{AGUTo}=500$ $\operatorname{mm}$ and $\varphi=0,72)$.

\section{1 - Monte dos Fortes watershed}

The results of simulations for 11 - Monte dos Fortes has many acceptable solutions (NSE > 0.5) for a broad spectrum of values of both $\varphi$ and AGUT (Supplementary Materials Fig. 24). In Figure 10 it is possible to observe that the model reproduces the behaviour of the measured flow following the rainfall occurrence and generally severe peaks in measured flow well reproduced, with minor deviation of computed values in smaller flow episodes. For the computed adjusted $\varphi$, no general differences are observed between the response of the model to rainfall with different values of AGUTo in different $\mathrm{I}_{\mathrm{p}}$. It is important to note that this watershed shows a relevant SF Rainfall ratio of $30 \%$.

Considering the $50 \% \mathrm{I}_{\mathrm{p}}$, which is not the expected percentage of $I_{p}$ for the $C M$ established for this watershed, Figure 11 shows the monthly results of the model for different pairs of AGUTo and $\varphi$ ([120, 0.12], [120, 0.8], [240, 0.2] and [500, 0.8]). High [AGUTo, $\varphi$ ] pair (500, 0.8) shows a relevant underestimation of $\mathrm{E}_{\text {total }}$, while the other pairs show similar results between themselves and $\mathrm{NSE}_{\max }>0.7$. For this watershed, AGUT variation took a more significant impact on the results if compared with the variation of $\varphi$.

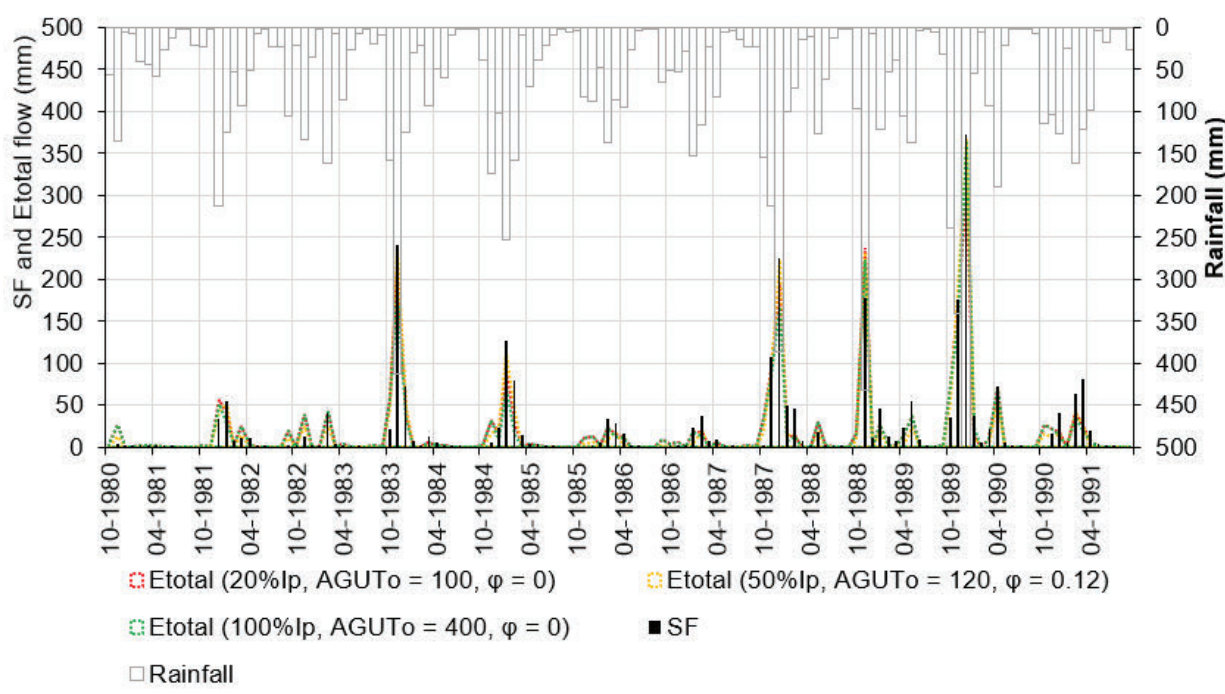

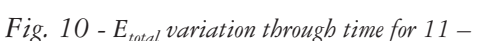
Monte dos Fortes.

Fig. 10 - Variazione di $\mathrm{E}_{\text {total }}$ nel tempo per 11 - Monte dos Fortes. 


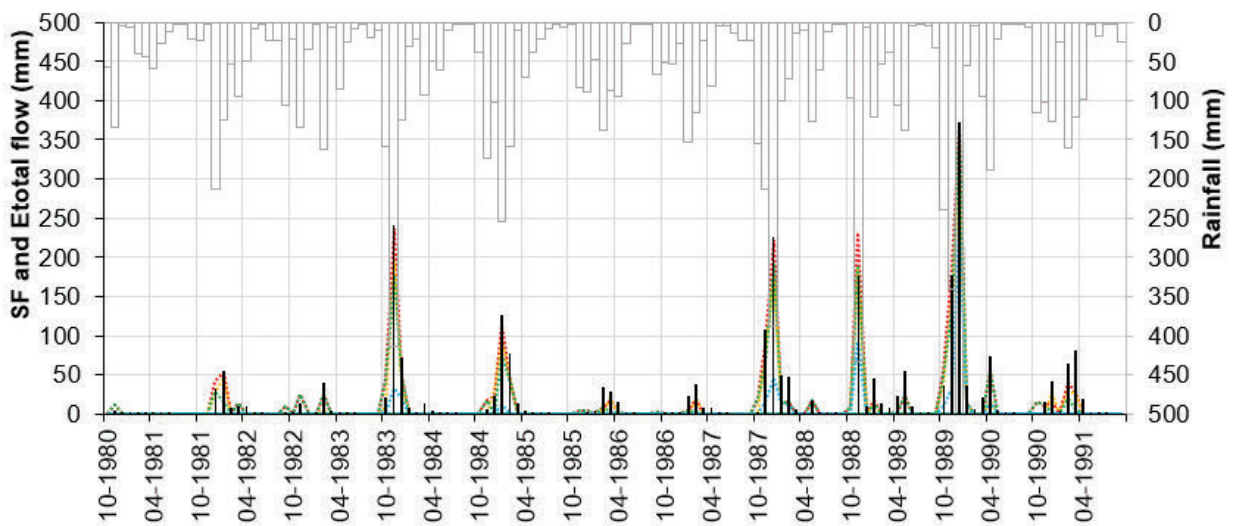

Etotal (50\%lp, AGUTo $=120, \varphi=0.12)$

Etotal (50\%lp, AGUTo $=240, \varphi=0.12)$

- SF

Etotal (50\%lp, AGUTo $=120, \varphi=0.8)$

Etotal (50\%lp, AGUTo $=500, \varphi=0.8)$

$\square$ Rainfall

Fig. 11 - Comparison between results for different pairs of adjusted $\varphi$ and AGUTo but with $I_{p}$ that showed the best adjustment for 11 - Monte dos Fortes.

Fig. 11 - Confronto tra i risultati di diverse coppie di $\varphi$ corretti e AGUTo, ma con $I_{p}$ che presenta la miglior interpolazione per 11 Monte dos Fortes.

AGUTo, which lower the $\mathrm{E}_{\mathrm{d}}$ and increase the $\mathrm{I}_{\mathrm{p}}$, ultimately lowering $\mathrm{E}_{\text {total }}$ (for the lowest $\mathrm{I}_{\mathrm{p}}$ considered in the simulations $-20 \%$ ). This is also observed in 21 - Sítio Igreja results (SF Rainfall ratio of $5 \%$ ) although they belong to different CM groups - cf. Supplementary Materials (Fig. 32).

Figure 13 and Figure 14 show the computed model results for monthly $\mathrm{E}_{\text {total }}$ with $20 \% \mathrm{I}_{\mathrm{p}}$ and different $\varphi$ with the same AGUTo and different AGUTo with the same $\varphi$, respectively. It is possible to observe, with AGUTo $=500 \mathrm{~mm}$, that lower

karstic rocks), the model will rely on high values of $\varphi$ and
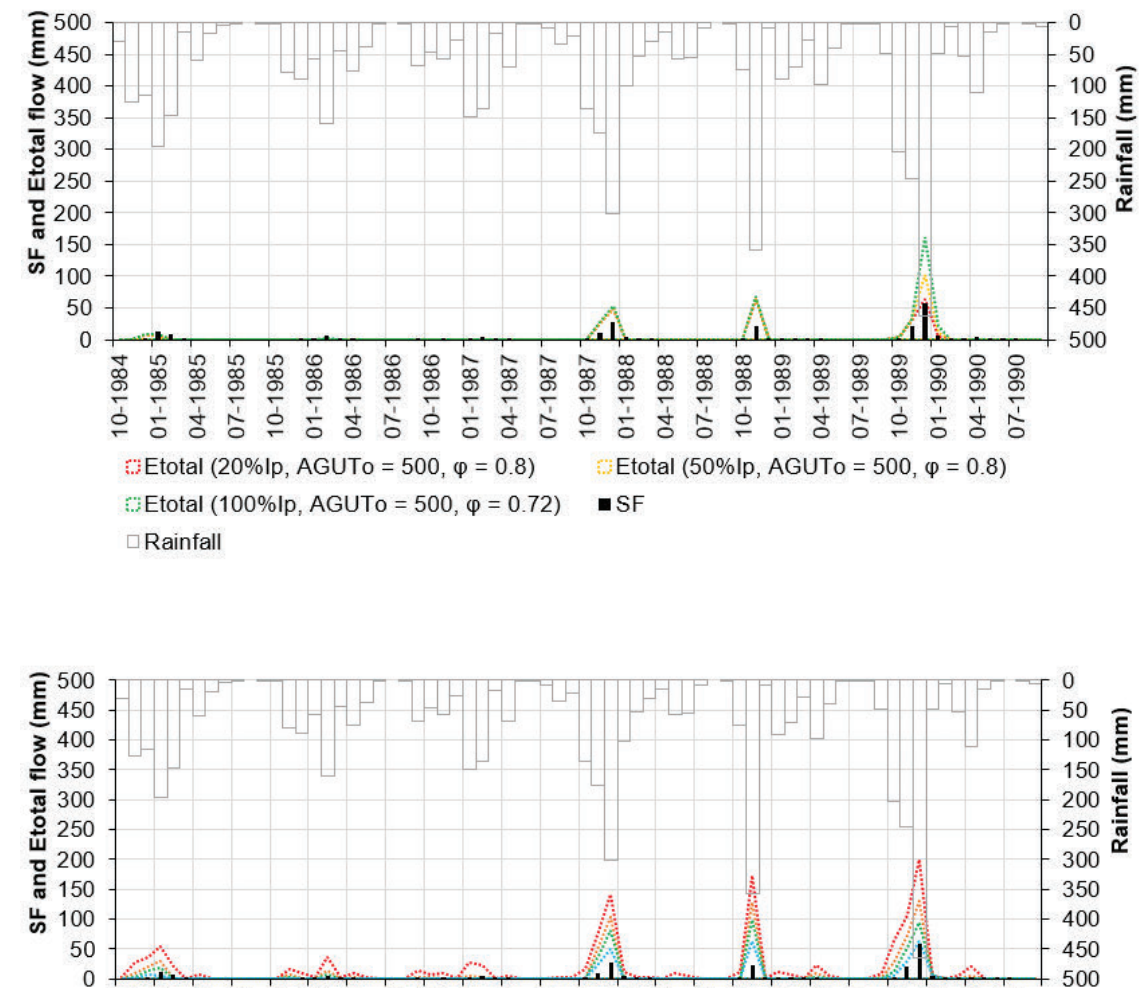

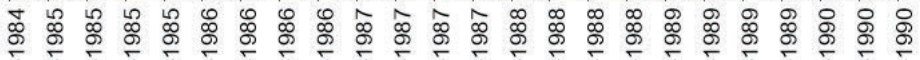

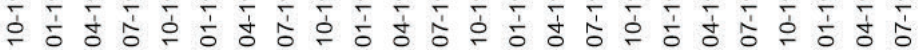

Etotal $(20 \% \mathrm{lp}$, AGUTo $=500, \varphi=0)$

Etotal $(20 \%$ lp, AGUTo $=500, \varphi=0.4)$

- $\mathrm{SF}$

Etotal $(20 \% \mid p$, AGUTo $=500, \varphi=0.8)$

$\square$ Rainfall
Fig. $12-E_{\text {total }}$ variation through time for $17-$ Ponte Mesquita.

Fig. 12 - Variazione di $\mathrm{E}_{\text {total }}$ nel tempo per 17 - Ponte Mesquita.
Fig. 13 - Comparison between results for different values of adjusted $\varphi$ and static AGUTo and $I_{p}$ that showed the best adjustment for 17 - Ponte Mesquita.

Fig. 13 - Confronto tra i risultati per diversi valori di $\varphi$ corretti, AGUTo statico e $\mathrm{I}_{\mathrm{p}}$ che presenta la miglior interpolazione per 17 - Ponte Mesquita. 


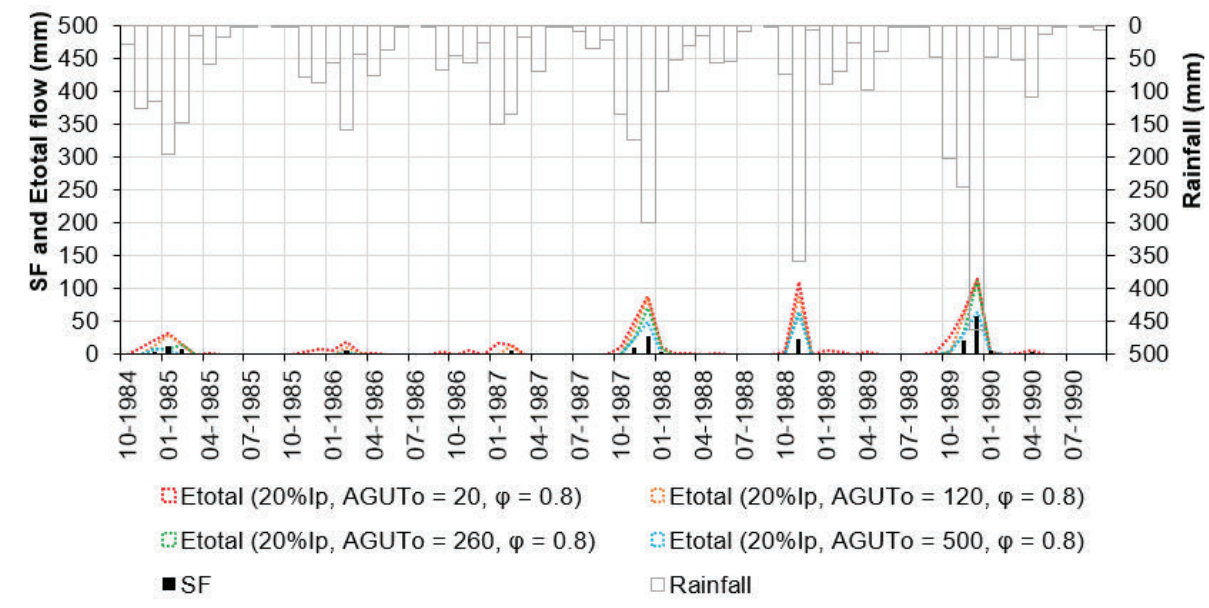

Fig. 14 - Comparison between results for static values of adjusted $\varphi$, variable AGUTo and $I_{p}$ that showed the best adjustment for 17 - Ponte Mesquita.

Fig. 14 - Confronto tra i risultati per valori statici di $\varphi$ corretti, AGUTo variabili and $I_{p}$ che presenta la miglior interpolazione per 17 - Ponte Mesquita. $\varphi$ results in higher computed $\mathrm{E}_{\text {total }}$ as expected, decreasing as $\varphi$ increases. With a maximum value of $\varphi$ considered in the simulations (0.8) the decrease of AGUTo results in a decrease of $\mathrm{E}_{\text {total }}$. This confirms that BALSEQ should be used carefully in areas with low SF and with relevant karstic regions or highly permeable sedimentary formations. In the simulations conducted it is perceptible that in the referred watersheds better adjustments could be achieved if $\mathrm{x} \% \mathrm{I}_{\mathrm{p}}$ was closer to 0 .

\section{Comparison of results between the two procedures for sensitivity analysis}

Comparing the two approaches of sensitivity analysis ([1] static AGUT, variable $I_{p}$ and $\varphi$ vs [2] variable AGUT, $I_{p}$ and $\varphi$ ) for the whole dataset, and looking specifically at the maximum NSE and the adjustments between different $\mathrm{x} \% \mathrm{I}_{\mathrm{p}}$, it is possible to observe that the increase of $\mathrm{I}_{\mathrm{p}}$ resulted in an increase in the number of watersheds with $\mathrm{NSE}_{\max }>0.5$ (Fig. 15). The tuning of AGUT from the initially computed value resulting from the methods initially established in Vermeulen et al. (1993) may be relevant to achieve more accurate results.

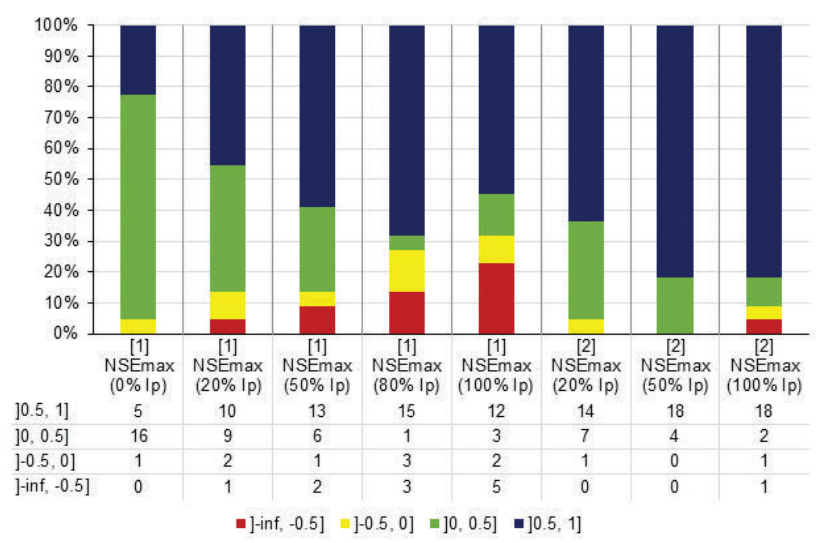

Fig. 15 - Variations of NSE $E_{\max }$ with different $I_{p}$ and simulation methods.

Fig. 15 - Variazioni di NSE $_{\max }$ per diversi valori di $\mathrm{I}_{\mathrm{p}}$ e di metodi di simulazione.

\section{Conclusions}

The overall results show that it may be difficult to reach the clear conclusion that the parameter $\varphi$, defined as 0.2 , is overestimated and inadequate for the studied region, but they confirm the assumptions of Correia (1984) and Portela et al. (2000) that this parameter should not be overlooked when applying the SCS $\mathrm{E}_{\mathrm{d}}$ calculation method outside the area for which it was defined.

No clear relations were identified between the $\varphi$ parameter and the watershed characteristics, such as yearly averaged rainfall, $\mathrm{CN}$ or between optimized $\mathrm{AGUT}$ and $\mathrm{CN}$ (both reflect the soil type and land use), even if this evaluation is conducted for groups of watersheds with the same conceptual model that considers the different contribution that deep infiltration can have in the total flow $\left(\mathrm{E}_{\text {total }}=\mathrm{E}_{\mathrm{d}}+\mathrm{x} \% \mathrm{I}_{\mathrm{p}}\right.$ or $\mathrm{E}_{\text {total }}=\mathrm{x} \% \mathrm{I}_{\mathrm{p}}$ for karstic areas where $\mathrm{x}$ is low, and $\mathrm{E}_{\mathrm{d}}$ is negligible). By not being possible to identify clear relations between the studied variables it is therefore not possible to define a model to extrapolate an adjusted $\varphi$ to other ungauged watersheds. The results seem to express that the variation of $\varphi$ and AGUT occur under the influence of other phenomena not considered in BALSEQ inputs and that may influence the hydrological behaviour of the watershed, particularly the influence, at local scale, of the exchanges between surface and groundwater in geologically heterogeneous watersheds. Also, AGUT is computed based on the root depth of vegetation, which is itself a parameter that varies throughout the year, particularly in agricultural regions. In future simulations, a seasonal varying of AGUT - similar to varying $\mathrm{CN}$ given antecedent moisture conditions - can be developed and integrated into the model.

The main problem with the adopted sensitivity analysis procedures is directly related to the model returning similar results for a large set of different parameters considered. For the simulation results with AGUTp (cf. Supplementary Materials, Fig. 17), the variation of $\varphi$ shows little effect in NSE values, even for different percentages of $I_{p}$ in certain watersheds. In this method, for $\mathrm{I}_{\mathrm{p}}$ below $20 \%$, there is a better adjustment (maximum NSE) for lower values of $\varphi$. 
For the simulations with varying AGUT (cf. Supplementary Materials, Fig. 20 to Fig. 32), it is possible to identify intervals of optimized AGUT values in many of the studied watersheds but, again, low differences in NSE are observed with variation of $\varphi$. The exception is 17 - Ponte Mesquita and 21 - Sítio Igreja, watersheds, with low SF-Rainfall ratio and different conceptual models, where acceptable adjustments are computed only in a constrict interval of AGUT and $\varphi$, both high, to handle low values of SF.

Although it was not possible to correlate intrinsic characteristics of the watersheds with adjusted parameters, it was possible to understand that, if the BALSEQ model is to be applied in a large geologically heterogeneous region, it should be considered that the total flow results from the conjugation of direct runoff and an important contribution of the $I_{p}$ (above $50 \%$ in many parts of the region). The appreciation of the adjustments may deter the use of the BALSEQ model for the evaluation of extreme events, as it may not keep up with peaks of flow (at monthly scale) specifically in some watersheds where the SF-Rainfall ratio is low, which evidence critical losses due possibly to deep infiltration. As BALSEQ always calculates $E_{d}$, the model must be used with caution when comparing with SF from watersheds with important karstic influence near the gauging station, or sedimentary watersheds where infiltration is significant and does not contribute to the groundwater discharge within its bounds (e.g., discharges to the sea). Also, BALSEQ overestimates the $\mathrm{E}_{\text {total }}$ for the predefined $\mathrm{CMs} \times \mathrm{x} \% \mathrm{I}_{\mathrm{p}}$ which may indicate that the used approach is oversimplistic.

Studies at a regional scale must cope with increased degrees of uncertainty related, e.g., with mapping of initial parameters such as $\mathrm{CN}$ or AGUT but also with rainfall and PET series. The simulations at these scales may lack the detail for the implementation required (e.g., MAR methods) giving a more general overview of the water availability. It must be considered that the considered data was not for a common period of analysis, which only allowed for the comparison among average values which may integrate meteorological anomalies (e.g., a long period of drought or rainfall variability). We suggest that further synchronous studies are conducted in small geologically and pedologically homogeneous watersheds located within the study region, gathering complete SF, rainfall and PET series coupled with soil characterization, which ultimately may help to define a model of calibration to be applied in non-monitored regions.

\section{Acknowledgements}

This paper was developed in the framework of LNEC's 2013-2020 Research and Innovation Plan, Risk Management and Safety in Hydraulics and Environment (Process Nr. 0605/112/20383). Tiago N. Martins thanks the Fundação para a Ciência e a Tecnologia (FCT), Portugal for the Ph.D. Grant $\mathrm{PD} / \mathrm{BD} / 135590 / 2018$

Competing interest

The authors declare no competing interest.

\section{REFERENCES}

Alam S, Borthakur A, Ravi S, Gebremichael M, Mohanty SK (2021) Managed aquifer recharge implementation criteria to achieve water sustainability. Science of The Total Environment 768, 144992. https://doi.org/10.1016/j.scitotenv.2021.144992

Beven KJ (2012) Rainfall-Runoff Modelling: The Primer. John Wiley \& Sons, Ltd, Chichester, UK. https://doi.org/10.1002/9781119951001

Chachadi AG, Raikar PS, Lobo Ferreira JP, Oliveira MM (2001) GIS and Mathematical Modelling for the Assessment of Groundwater Vulnerability to Pollution: Application to an Indian Case Study Area in Goa. LNEC Report 115/01-GIAS, Lisbon.

Chachadi AG, Choudri BS, Lobo Ferreira JP (2005) Estimation of Surface Runoff and Groundwater Recharge in Goa Mining Area Using Daily Sequential Water Balance Model - BALSEQ. Tunnelling and Underground Space Technology, 15.

Chow V, Maidment D, Mays L (1988) Applied Hydrology. McGrawHill Book Company, New York.

Correia FN (1984) Proposta de um método para a determinação de caudais de cheia em pequenas bacias naturais e urbanas "Proposed method for the determination of flood flows in small natural and urban watersheds". LNEC Technical Report ITH 6, Lisbon.

Costa WD, Marinho JM, Castelo Branco RL, Sousa SL, Ramos A, Oliveira MM, Leitão TE, Mendes AC, Martins TAN, Teixeira JAC (2019) Relatório síntese da modelagem numérica (RTP-6) (Relatório de Atividade No. 14), Estudos Hidrogeológicos e de Modelagem Numérica para Identificação do Potencial dos Aquíferos das Bacias Sedimentares de Cedro, Carnaubeira da Penha, Mirandiba e Betânia "Numerical modeling synthesis report (RTP-6) (Activity Report No. 14), Hydrogeological and Numerical Modeling Studies for Identifying the Aquifer Potential of the Cedro, Carnaubeira da Penha, Mirandiba and Betânia Sedimentary Basins". Secretaria de Desenvolvimento Econômico, Recife, Pernambuco.

Dillon PJ, Pavelic P, Page D, Beringen H, Ward J (2009) Managed aquifer recharge. An introduction. Waterlines Report Series, 13, 1-64. Available from: https://recharge.iah.org/files/2016/11/MAR_ Intro-Waterlines-2009.pdf

Durão RM, Pereira MJ, Costa AC, Delgado J, del Barrio G, Soares A (2010) Spatial-temporal dynamics of precipitation extremes in southern Portugal: a geostatistical assessment study. Int. J. Climatol., 30: 1526-1537pp. https://doi.org/10.1002/joc.1999

Gassert F, Luck M, Landis M, Reig P, Shiao T (2015) Aqueduct Global Maps 2.1: Constructing Decision-Relevant Global Water Risk Indicators. World Resources Institute. Available from: https://www. wri.org/research/aqueduct-global-maps-21-indicators

Hofstra N, Haylock M, New M, Jones P, Frei C (2008) Comparison of six methods for the interpolation of daily, European climate data. J. Geophys. Res. 113, D21110. https://doi.org/10.1029/2008JD010100

Leitão TE, Oliveira MM, Lobo Ferreira JP, Moinante MJ, Diamantino C, Henriques MJ (2001) Estudo das condições ambientais no estuário do Guadiana e zonas adjacentes. Componente Águas subterrâneas. Diagnóstico da situação actual e identificação da situação de referência "Study of environmental conditions in the Guadiana estuary and adjacent areas. Groundwater component. Diagnosis of the Current Situation and Identification of the Reference Situation". $2^{\text {nd }}$ Phase LNEC report 212/01-GIAS, Lisbon.

Leitão TE, Duarte Costa W, Oliveira MM, Novo ME, Martins T, Henriques MJ, Charneca N, Lobo Ferreira JP, Viseu MT, Santos MAV, Cabral JJ, Freitas Filho A (2017) Estudos sobre a Disponibilidade e Vulnerabilidade dos Recursos Hídricos Subterrâneos da Região Metropolitana do Recife. Relatório da Atividade 9: Síntese dos resultados da modelagem numérica "Studies on the Availability and Vulnerability of Groundwater Resources at the Recife Metropolitan Region. Report on Activity 9: Synthesis of the numerical modelling results". APAC - Water and Climate Pernambuco Agency. Internal report, Recife, Brazil. 
Ling, L, Yusop, Z, Yap, W-S, Tan, WL, Chow, MF, Ling, JL (2019) A Calibrated, Watershed-Specific SCS-CN Method: Application to Wangjiaqiao Watershed in the Three Gorges Area, China. Water 12, 60pp. https://doi.org/10.3390/w12010060

Lobo Ferreira JP (1981) Mathematical Model for the Evaluation of the Recharge of Aquifers in Semiarid Regions with Scarce (Lack) Hydrogeological Data. Proceedings of Euromech 143/2-4 Sept. 1981, Rotterdam, A.A. Balkema (Ed. A. Verruijt \& F.B.J. Barends). Also in LNEC Memoir \#582 (1982)

Maliva R (2014) Economics of Managed Aquifer Recharge. Water 6, 1257-1279. https://doi.org/10.3390/w6051257

Martins TN, Oliveira MM, Portela MM, Leitão TE (2021) Evaluation of the SCS-Curve Number Distribution in Southern Portuguese Watersheds. 15th Portuguese Water Conference. Portuguese Water Resources Association (APRH), Lisbon.

Moriasi DN, Arnold JG, Van Liew MW, Bingner RL, Harmel RD, Veith TL (2007) Model Evaluation Guidelines for Systematic Quantification of Accuracy in Watershed Simulations. Transactions of the ASABE 50, 885-900. https://doi.org/10.13031/2013.23153

Moriasi DN, Gitau M, Pai N, Daggupati P (2015) Hydrologic and Water Quality Models: Performance Measures and Evaluation Criteria. Transactions of the ASABE 58, 1763-1785. https://doi. org/10.13031/trans.58.10715

Novo ME, Leitão TE, Tore C, Lobo Ferreira JP (1994) Avaliação dos Recursos hídricos subterrâneos da Ilha da Madeira "Evaluation of the groundwater resources of Madeira Island". LNEC Report 99/94GIAS, Lisbon.

Oliveira MM. (2004/2006) Recarga de Águas Subterrâneas - Métodos de Avaliação "Groundwater Recharge - Assessment Methods". LNEC PhD Thesis.

Oliveira MM, Moinante MJ, Lobo Ferreira JP (1997) Cartografia automática da vulnerabilidade de aquíferos com base na aplicação do Método DRASTIC "Automatic mapping of aquifer vulnerability based on the application of the DRASTIC Method". Final report. LNEC 60/97-GIAS, Lisbon.

Oliveira, LGS (2007) Soluções para uma gestão adequada de bacias hidrográficas e de sistemas aquíferos, em cenários de escassez hídrica extrema. Aplicação ao sistema aquífero Querença-Silves(Algarve) no âmbito da Acção de Coordenação ASEMWaternet "Solutions for an adequate management of hydrographic basins and aquifer systems, in scenarios of extreme water scarcity. Application to the QuerençaSilves aquifer system (Algarve) within the scope of the ASEMWaternet Coordination Action". MSc dissertation, Instituto Superior Técnico, Lisbon.

Oliveira MM, Lobo Ferreira JP (1999) Comparação dos valores de recarga das águas subterrâneas obtidos pela aplicação de diferentes métodos em áreas seleccionadas dentro da área do Plano de Bacia do Tejo "Comparison of groundwater recharge values obtained by applying different methods in selected areas within the area of the Tagus Basin Plan". Portuguese Groundwater Seminar, Portuguese Water Resources Association (APRH), Lisbon.

Jeon J-H, Lim K, Engel B (2014) Regional Calibration of SCS-CN L-THIA Model: Application for Ungauged Basins. Water 6, 13391359. https://doi.org/10.3390/w6051339

Page D, Bekele E, Vanderzalm J, Sidhu J (2018) Managed aquifer recharge (MAR) in sustainable urban water management. Water 10, 239. https://doi.org/10.3390/w10030239

Ponce VM, Hawkins RH (1996) Runoff Curve Number: Has It Reached Maturity? Journal of Hydrologic Engineering 1, 11-19. https://doi.org/10.1061/(ASCE)1084-0699(1996)1:1(11)

Portela, MM, Silva, AT, Melim, CP (2000) O Efeito da Ocupação Urbana nos Caudais de Ponta de Cheias Naturais em Pequenas Bacias Hidrográficas "The Effect of Urban Occupation on Peak Flood Flows in Small Hydrographic Basins". $5^{\text {th }}$ Portuguese Water Congress (APRH), Lisbon.
Portuguese Environmental Agency (APA) (2020) Bases do Plano Regional de Eficiência Hídrica - Região do Algarve "Basis of the Regional Water Efficiency Plan - Algarve Region". Volume I Descriptive memory. Available from: https://apambiente.pt/_zdata/ Apresentacoes/2020/PlanoRegEficienciaHidricaAlg/PlanoEH_ Algarve_VFinal_26Ago2020__VOL_I.pdf

Ramos C, Reis E (2002) Floods in Southern Portugal: their physical and human causes, impacts and human response. Mitigation and Adaptation Strategies for Global Change 7(3) 267 - 284pp. https:// doi.org/10.1023/A:1024475529524

Santos JF, Pulido-Calvo I, Portela MM (2010) Spatial and temporal variability of droughts in Portugal, Water Resour. Res., 46, W03503. https://doi.org/10.1029/2009WR008071

Trigo RM, Da Camara CC (2000) Circulation weather types and their influence on the precipitation regime in Portugal, Int. J. Climatol., vol. 20. https://doi.org/10.1002/10970088(20001115)20:13\%3C1559::AID-JOC555\%3E3.0.CO;2-5

Sophocleous M (2002) Interactions between groundwater and surface water: the state of the science. Hydrogeology Journal 10, 52-67. https://doi.org/10.1007/s10040-001-0170-8

U.S. Department of Agriculture - Natural Resources Conservation Service (USDA-NRCS) (2004) Estimation of Direct Runoff from Storm Rainfall. Chapter 10. Part 630. National Engineering Handbook. Available from: https://directives.sc.egov.usda.gov/ OpenNonWebContent.aspx? content=17752.wba

Vermeulen H, Lobo Ferreira JP, Oliveira MM (1993) A method for estimating aquifer recharge in DRASTIC vulnerability mapping, 1st Portuguese Groundwater Seminar, APRH, Lisbon.

Additional information

Supplementary information is available for this paper at

https://doi.org/10.7343/as-2021-514

Reprint and permission information are available writing to

acquesotterranee@anipapozzi.it

Publisher's note Associazione Acque Sotterranee remains neutral with regard to jurisdictional claims in published maps and institutional affiliations. 